\title{
Effects of equal channel angular pressing and heat treatments on the microstructures and mechanical properties of selective laser melted and cast AISi10Mg alloys
}

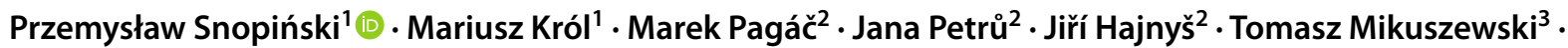 \\ Tomasz Tański ${ }^{1}$
}

Received: 8 January 2021 / Revised: 14 April 2021 / Accepted: 12 May 2021 / Published online: 27 May 2021

(C) The Author(s) 2021

\begin{abstract}
This study investigated the impact of the equal channel angular pressing (ECAP) combined with heat treatments on the microstructure and mechanical properties of AlSi10Mg alloys fabricated via selective laser melting (SLM) and gravity casting. Special attention was directed towards determining the effect of post-fabrication heat treatments on the microstructural evolution of AlSi10Mg alloy fabricated using two different routes. Three initial alloy conditions were considered prior to ECAP deformation: (1) as-cast in solution treated (T4) condition, (2) SLM in T4 condition, (3) SLM subjected to lowtemperature annealing. Light microscopy, transmission electron microscopy, X-ray diffraction line broadening analysis, and electron backscattered diffraction analysis were used to characterize the microstructures before and after ECAP. The results indicated that SLM followed by low-temperature annealing led to superior mechanical properties, relative to the two other conditions. Microscopic analyses revealed that the partial-cellular structure contributed to strong work hardening. This behavior enhanced the material's strength because of the enhanced accumulation of geometrically necessary dislocations during ECAP deformation.
\end{abstract}

Keywords AlSi10Mg $\cdot$ Cast $\cdot$ Selective laser melting $\cdot$ Microstructure $\cdot$ Equal channel angular pressing

Przemysław Snopiński

przemyslaw.snopinski@polsl.pl

Mariusz Król

mariusz.krol@polsl.pl

Marek Pagáč

marek.pagac@vsb.cz

Jana Petrů

jana.petru@vsb.cz

Jiří Hajnyš

jiri.hajnys@vsb.cz

Tomasz Mikuszewski

tomasz.mikuszewski@polsl.pl

1 Department of Engineering Materials and Biomaterials, Silesian University of Technology, 18A Konarskiego Street, 44-100 Gliwice, Poland

2 Center of 3D Printing Protolab, Department of Machining, Assembly and Engineering Technology, Faculty of Mechanical Engineering, VSB-TU Ostrava, 17. Listopadu 2172/15, Ostrava-Poruba 708 00, Czech Republic

3 Department of Materials Science, Silesian University of Technology, Krasińskiego 8, 40-019 Katowice, Poland

\section{Introduction}

Metal additive manufacturing (AM) is a very promising technology that allows the fabrication of complex metallic parts using powders as raw materials. The novelty of AM manifests as somewhat of a disadvantage relative to other manufacturing processes, such as casting; however, this also means that there are numerous interesting development opportunities. Such improvements can be implemented in any of the steps during the metal AM processing chain, i.e., new alloys and powder development, parameter optimization, or post-processing treatment. Currently, the development of post-processing technologies (e.g., thermal, i.e., precipitation heat treatment [1], mechanical-i.e., ultrasonic peening [2] and chemical treatments, i.e., machining and brightening [3]) is particularly attractive because they may enhance the properties of the components fabricated via AM.

Hot isostatic pressing (HIP) is one of the most common strategies applied for the post-processing treatment of parts fabricated using selective laser melting (SLM) techniques. 
In this context, Liu et al. [4] studied the effect of HIP on the mechanical properties of the AZ61 magnesium alloy and found that SLM + HIP yielded an alloy that exhibited slightly lower YS (yield strength) and TS (tensile strength), but higher ductility than the analogous SLM counterpart. Wang et al. [5] employed HIP as a post-processing procedure on the AlSi10Mg alloy and observed that YS and TS decreased from $\sim 210$ and $\sim 40 \mathrm{MPa}$ to $\sim 208$ and $240 \mathrm{MPa}$, respectively. Similar results were observed by Yu et al., who subjected the Ti-6Al-V alloy to HIP treatment [6]. Additional research efforts have aimed at improving the mechanical properties of laser powder bed fabricated (LPBF) alloys using AmpliFORGE ${ }^{\mathrm{TM}}$ [7] and shot peening [8] techniques, which can reduce porosity/residual stresses and/or prolong fatigue life.

Alternative, less common strategies include the use of severe plastic deformation as a final post-processing procedure. Such technologies have significant potential in terms of improving the mechanical properties of metals fabricated via SLM. Their utility is based on the Hall-Petch relationship, which describes how the yield stress depends on the grain size [9]. This relationship is based on Eq. (1),

$\sigma_{\mathrm{y}}=\sigma_{0}+k_{\mathrm{y}} d^{-1 / 2}$

which demonstrates that the metal yield strength $\left(\sigma_{\mathrm{y}}\right)$ increases with decreasing grain sizes $(d)$, i.e., "smaller is stronger". In this context, Yusuf et al. [10] studied the effect of high-pressure torsion on the microstructural evolution and strength of SLM AlSi10Mg aluminum alloy and 316L steel. The results indicated a significant improvement in the hardness of the AlSi10Mg alloy (from 140 to $220 \mathrm{HV}$ ) and $316 \mathrm{~L}$ steel (from $\sim 240$ to $\sim 600 \mathrm{HV}$ ) which the authors of the following article [11] explained based on the extreme grain refinement and high dislocation densities originating from the unique heterogeneous microstructure.

However, there is still limited information regarding the microstructural evolution and mechanical properties of SLM-fabricated parts subjected to equal channel angular pressing (ECAP). This technique is especially attractive because it is suitable for reasonably sized specimen and according to Segal's work [12] can be scaled-up relatively easily to produce bulk (plate billets of the size $610 \times 610 \times 100 \mathrm{~mm}$ and a weight of $100 \mathrm{~kg}$ ) ultra-finegrained materials that can be used for a wide range of structural applications. According to Valiev and Langdon [13] during ECAP a sample is pressed through a die composed of two channels with identical cross sections, which intersect one another at a designated angle (typically $90^{\circ}$ or $120^{\circ}$ ). Although the process is discontinuous, it can be repeated many times to achieve the required strain accumulation, and this leads to grain refinement, which significantly strengthens the material. However, despite multiple advantages (i.e., ability to process large samples or scale up), ECAP has many disadvantages, including the fact that it requires large extrusion forces and materials with proper technological plasticity.

Tridello et al. [14], Salmi et al. [15], Ali et al. [16], and other researchers $[17,18]$ have found that most AM materials exhibit very high mechanical strength (higher than conventionally obtained for analogous parts). However, the large temperature gradients during the fabrication process cause high levels of residual stress within the metallic structure, thus post-SLM heat treatments are usually required to improve the ductility of SLM parts. Treatments aimed at increasing ductility and/or reducing residual stresses can be summarized as low-temperature annealing (typically between $280-320^{\circ} \mathrm{C}$ ) [19] or platform heating during fabrication (usually conducted at $35-200{ }^{\circ} \mathrm{C}$ ) [20].

In this report, we introduce a new approach for fabricating high-strength additively manufactured parts, wherein low-temperature annealing is applied as an intermediate procedure (to increase ductility and minimize residual stress), which precedes the final equal channel angular pressing step. Employing low-temperature annealing has a key advantage; specifically, a short period of heat treatment only leads to a partial change (modification) of the unique cellular structure, which is dramatically different from that of analogous alloy obtained by conventional casting.

To our knowledge, this study is the first in which selective laser melted samples were subjected to severe plastic deformation via ECAP. Herein, we also compare the deformation behavior of the same alloy obtained via different routes because the partial-cellular microstructure (heterogeneous) of SLM alloys offers higher dislocation storage capacity/ strain hardening ability than the conventional dendritic structure of cast counterparts.

Accordingly, we investigated the influence of ECAP processing on the microstructure and mechanical properties of SLM-manufactured versus cast AlSi10Mg alloys subjected to up to four ECAP passes. The microstructural evolution of the ECAP-processed AlSi10Mg alloy was characterized by optical microscopy, scanning electron microscopy (SEM), transmission electron microscopy (TEM), and X-ray diffraction (XRD), as well as Vickers microhardness (HV) and compression tests.

\section{Experimental materials and methods}

The SLM samples were fabricated from gas-atomized AlSi10Mg powder (Fig. 1) supplied by Sigma Aldrich, with a specified particle size range of $20-80 \mu \mathrm{m}$. The nominal chemical composition of the SLM powder is given in Table 1, and the exact composition measured via EDX is given in Fig. 1. 

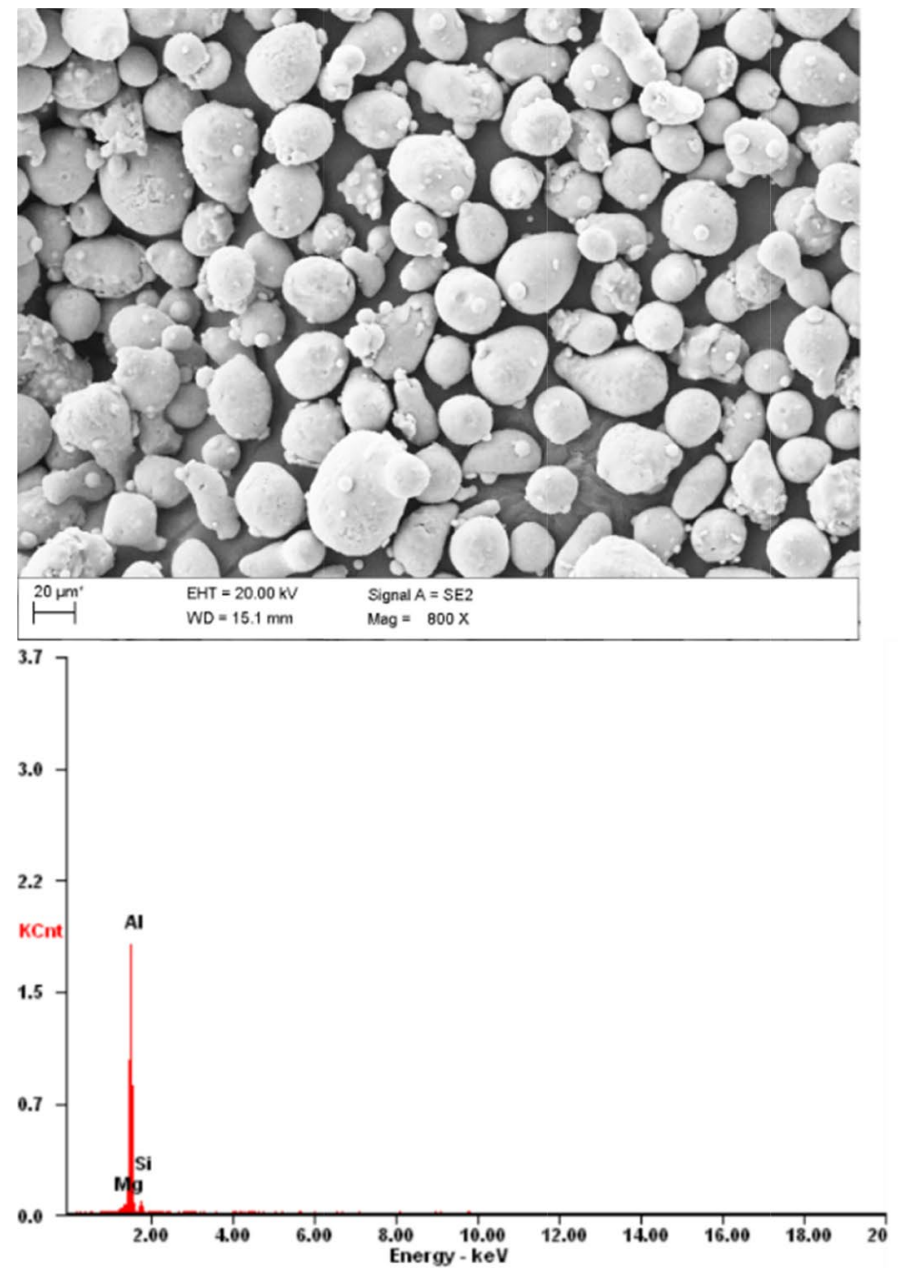

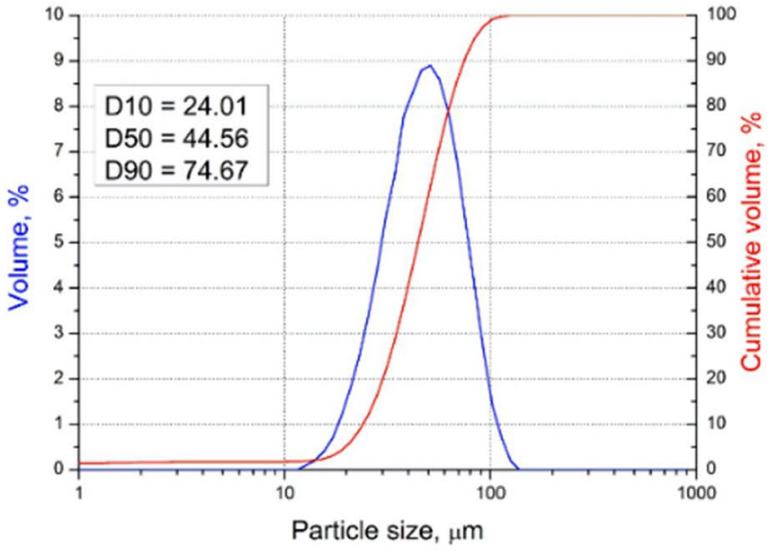

\begin{tabular}{|l|l|l|}
\hline Element & $\boldsymbol{W t} \%$ & $\boldsymbol{A t} \%$ \\
\hline $\boldsymbol{M g} \boldsymbol{K}$ & 01.30 & 01.51 \\
\hline $\boldsymbol{A l K}$ & 89.37 & 89.10 \\
\hline SiK & 09.33 & 09.39 \\
\hline Matrix & Correction & ZAF \\
\hline \hline
\end{tabular}

Fig. 1 SEM image and corresponding particle size distributions of AlSi10Mg powder (top) and results of EDS analysis (bottom)

Table 1 Chemical composition of the AlSi10Mg alloy (wt.\%)

\begin{tabular}{lllllllll}
\hline $\mathrm{Si}$ & $\mathrm{Mg}$ & $\mathrm{Fe}$ & $\mathrm{Ti}$ & $\mathrm{Zn}$ & $\mathrm{Mn}$ & $\mathrm{Ni}$ & $\mathrm{Co}$ & $\mathrm{Al}$ \\
\hline $9-11$ & $0.25-0.45$ & $<0.25$ & $<0.15$ & $<0.10$ & $<0.10$ & $<0.05$ & $<0.05$ & Balance \\
\hline
\end{tabular}

The TruPrint 1000 system from Trumpf was used to fabricate components using the SLM technique. All components were prepared in an Ar environment with a constant oxygen level content maintained below $0.5 \%$. The process details (i.e., model slicing, scanning strategy, component orientation) were designed using the Materialise Magics software. A chessboard (Zig-Zag) scanning strategy was used to prepare the components, with each layer divided into a $4 \times 4 \mathrm{~mm}$ square block. To avoid overheating the manufactured samples, each layer $(n+1)$ was rotated $90^{\circ}$ with respect to the previous layer $(n)$. The samples were fabricated using the process parameters presented in Table 2 .

Cast samples were prepared by melting pure aluminum (EN AW-A199.98), technical pure silicon, and magnesium (EN-MB99.95-A). Aluminum and silicon were placed
Table 2 SLM process parameters applied for manufacturing the samples

\begin{tabular}{llll}
\hline Power, $\mathrm{W}$ & $\begin{array}{l}\text { Layer thickness, } \\
\mu \mathrm{m}\end{array}$ & $\begin{array}{l}\text { Focus beam diam- } \\
\text { eter, } \mu \mathrm{m}\end{array}$ & $\begin{array}{l}\text { Laser speed, } \\
\mathrm{mm} \mathrm{s}^{-1}\end{array}$ \\
\hline 175 & 20 & 55 & 1400 \\
\hline
\end{tabular}

directly in the crucible before smelting, and magnesium was added to the liquid solution at the end of the smelting process from the vacuum feeder. The melting was carried out in a Balzers induction vacuum furnace (VSG 02) in a crucible $\mathrm{Al}_{2} \mathrm{O}_{3}$ crucible. To prevent the evaporation of charge components, smelting was carried out in an argon atmosphere, under a pressure of about 600 Tor. Specifically, before the 
smelting process, the chamber was flushed three times with argon, each time pumping the gas to a pressure of about $10^{-3}$ Tor to minimize the amount of oxygen in the melting space. Smelting and casting were carried out at approx. $620^{\circ} \mathrm{C}$. Graphite molds were used at ambient temperature, with a rod-shaped cavity (length $=100 \mathrm{~mm}$, diameter $=20 \mathrm{~mm}$ ). The measured chemical composition of the as-cast samples is given in Table 3.

The samples manufactured via SLM and casting were brittle, which made ECAP processing difficult at room temperature. Therefore, after manufacturing, the samples were heat treated.

The SLM alloy heat treatment procedure was one of the following:

$\mathrm{S} 1$ - solution heat treatment for $1 \mathrm{~h}$ at $500{ }^{\circ} \mathrm{C}$. This caused complete disappearance of the heterogeneous cellular microstructure;

S2-low-temperature annealing for $8 \mathrm{~min}$ at $300{ }^{\circ} \mathrm{C}$. The purpose of this treatment was to remove residual stresses (increase technological plasticity). This type of a heat treatment allowed also a partial preservation of the unique heterogeneous cellular microstructure (typical for the laser powder bed fusion processes) as it demonstrated by Fiocchi et al. [19].

For the cast alloy, only one heat treatment procedure was applied:

$\mathrm{C} 1$ - solution heat treatment for $1 \mathrm{~h}$ at $500{ }^{\circ} \mathrm{C}$.
Detailed information about the heat treatment conditions and corresponding post-processing parameters is compiled in Table 4.

Prior to the ECAP process, cylindrical rods were machined to a diameter of $9.95 \mathrm{~mm}$. The obtained specimens were then lubricated using graphite grease and positioned in the $120^{\circ}$ ECAP die (imposing an equivalent strain of $\varepsilon=0.6$ per pass) to be deformed.

The equivalent strain was calculated using a generally used equation, given below:

$\varepsilon_{N}=\frac{N}{\sqrt{3}}\left\lfloor 2 \cot \left(\frac{\varphi}{2}+\frac{\psi}{2}\right)+\psi \csc \left(\frac{\varphi}{2}+\frac{\psi}{2}\right)\right\rfloor$

In this equation $\varepsilon_{N}$ is equivalent strain after $N$ passes, $N$ is the number of passes, $\psi$ is the angle associated with the arc of curvature, $\varphi$ is the channel angle.

Figure 2 illustrates the SLM sample orientation before the ECAP process and the external appearances of the AlSi10Mg alloy S2-1 and S2-2 samples.

For microstructural analysis, samples were prepared following standard metallographic procedures and then etched using Barker's (polarized light observation) and Keller's (bright field observation) reagents. Detailed information regarding the etching reagents' chemical compositions and the applied etching conditions can be found in our group's previous studies [21-24]. The microstructures of the samples were observed using an Axio Observer Z1 Light
Table 3 The measured chemical composition of the cast alloy

Table 4 Labeling scheme for the AlSi10Mg alloys and their corresponding post-processing conditions

\begin{tabular}{lllllllll}
\hline $\mathrm{Si}$ & $\mathrm{Mg}$ & $\mathrm{Fe}$ & $\mathrm{Ti}$ & $\mathrm{Zn}$ & $\mathrm{Mn}$ & $\mathrm{Ni}$ & $\mathrm{Co}$ & $\mathrm{Al}$ \\
\hline 10.98 & 0.82 & 0.026 & 0.0016 & 0.018 & 0.001 & $<0.001$ & $<0.001$ & Balance \\
\hline
\end{tabular}

\begin{tabular}{|c|c|c|}
\hline Sample ID & Initial condition & Post-processing conditions \\
\hline S0 & SLM & None \\
\hline S1 & SLM & Solution heat treatment $500{ }^{\circ} \mathrm{C} 1 \mathrm{~h}$ \\
\hline S1-1 & SLM & Solution heat treatment $500^{\circ} \mathrm{C} 1 \mathrm{~h} \rightarrow$ ECAP 1 pass \\
\hline S1-2 & SLM & Solution heat treatment $500^{\circ} \mathrm{C} 1 \mathrm{~h} \rightarrow$ ECAP 2 passes \\
\hline S1-3 & SLM & Solution heat treatment $500^{\circ} \mathrm{C} 1 \mathrm{~h} \rightarrow$ ECAP 3 passes \\
\hline S1-4 & SLM & Solution heat treatment $500^{\circ} \mathrm{C} 1 \mathrm{~h} \rightarrow$ ECAP 4 passes \\
\hline S2 & SLM & low-temperature annealing $300^{\circ} \mathrm{C} 8 \mathrm{~min}$ \\
\hline S2-1 & SLM & low-temperature annealing $300{ }^{\circ} \mathrm{C} 8 \mathrm{~min} \rightarrow$ ECAP 1 pass \\
\hline S2-2 & SLM & low-temperature annealing $300{ }^{\circ} \mathrm{C} 8 \mathrm{~min} \rightarrow$ ECAP 2 passes* \\
\hline $\mathrm{C} 0$ & Cast & As-cast \\
\hline $\mathrm{C} 1$ & Cast & Solution heat treatment $500^{\circ} \mathrm{C} 1 \mathrm{~h}$ \\
\hline $\mathrm{C} 1-1$ & Cast & Solution heat treatment $500^{\circ} \mathrm{C} 1 \mathrm{~h} \rightarrow$ ECAP 1 pass \\
\hline $\mathrm{C} 1-2$ & Cast & Solution heat treatment $500^{\circ} \mathrm{C} 1 \mathrm{~h} \rightarrow$ ECAP 2 passes \\
\hline $\mathrm{C} 1-3$ & Cast & Solution heat treatment $500^{\circ} \mathrm{C} 1 \mathrm{~h} \rightarrow$ ECAP 3 passes \\
\hline $\mathrm{C} 1-4$ & Cast & Solution heat treatment $500^{\circ} \mathrm{C} 1 \mathrm{~h} \rightarrow$ ECAP 4 passes \\
\hline
\end{tabular}

*Completing more than two ECAP passes for the S2 sample was not possible due to sample crumbling 

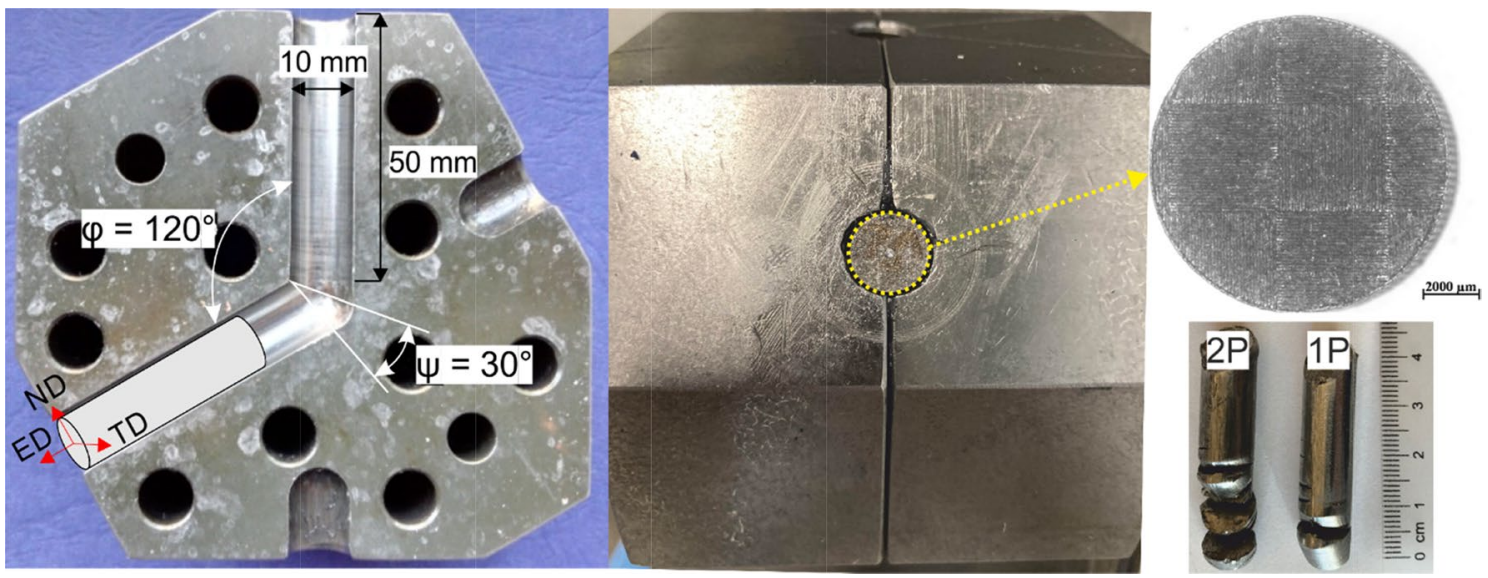

Fig. 2 ECAP die scheme used (left), sample orientation before the ECAP process (center) and the external appearances of SLM AlSi10Mg alloy samples after ECAP (right)

Microscope (LM) supplied by Zeiss (Carl Zeiss NTS GmbH, Oberkochen, Germany). Observations under higher magnification were conducted using a scanning electron microscope (Zeiss Supra 35) equipped with an energy-dispersive X-ray spectrometer (EDX), which allowed microanalysis of the chemical composition.

The thin foil microstructure was investigated using a high-resolution transmission electron microscope (JEM 3010 UHR, JEOL) at an accelerating voltage of $200 \mathrm{kV}$. For the TEM characterization, a $0.5 \mathrm{~mm}$ disc was sectioned from the center of the cross-section of the work samples ( $x$-plane). Then, the sample was electrolytically polished using a polishing solution $\left(30 \% \mathrm{HNO}_{3}+70 \% \mathrm{C}_{2} \mathrm{H}_{5} \mathrm{OH}\right)$ at $-30{ }^{\circ} \mathrm{C}$ with a DC voltage of $20 \mathrm{~V}$ until one or more holes appeared.

For the electron backscattered diffraction (EBSD) characterization, samples were electropolished using the same electrolyte as that used to prepare the TEM thin foils. The grain structure was recorded using orientation imaging microscopy (OIM) applying the EBSD technique integrated with a Zeiss Supra 35 SEM controlled and analyzed using OIM software (EDAX, Inc., Mahwah, NJ, USA). The step size was $0.06 \mu \mathrm{m}$ for all scans. A neighbor orientation correlation data cleaning process (level 4) was applied, followed by a grain confidence index standardization cleanup with a grain tolerance angle threshold of $2^{\circ}$. After the data cleaning, a coincidence index filter of 0.05 was used to remove any points that were not indexed correctly.

$\mathrm{X}$-ray diffraction analysis was carried out using a PANalytical X'Pert Pro diffraction system (Malvern Panalytical Ltd., Royston, UK) equipped with $\mathrm{CoK} \alpha$ radiation source. To remove the error due to instrument broadening in the experimental $\mathrm{X}$-ray diffraction profiles, the full-width at half-maximum (FWHM) in the peak profile of a fully annealed pure aluminum was used to determine structural broadening (i.e., effective FWHM). The phase composition was evaluated based on the XRD peaks, and the dislocation density was estimated from the microstrain $(\varepsilon)$ and crystallite size $(D)$ using software based on the Rietveld refinement method.

Then, the dislocation density was calculated using Eq. (3),

$\rho_{\mathrm{XRD}}=\left(\rho_{\mathrm{d}} \times \rho_{\mathrm{s}}\right)^{1 / 2}$

where $\rho_{\mathrm{s}}$ and $\rho_{\mathrm{d}}$ are the dislocation density due to the size effect and the dislocation density due to lattice strain, respectively.

To evaluate the mechanical properties of the processed materials, the microhardness (i.e., Vickers hardness, HV) values were measured using a microhardness tester (FutureTech FM-ARS) under a load of $300 \mathrm{~g}$ for $15 \mathrm{~s}$. The compressive tests were performed using samples with diameter $=5 \mathrm{~mm}$ and height $=10 \mathrm{~mm}$.

\section{Results}

\subsection{Initial state microstructure}

Figure $3 \mathrm{a}$ shows the polarized light micrograph of the asbuilt (S0) SLM AlSi10Mg alloy captured on the horizontal cross-section. Etching with Barker's reagent revealed the macrostructure of the examined alloy. The semicircular melt pools and scan tracks are visible, so the scanning strategy can be determined directly from the micrograph. In this case, the layers were melted using an alternating bi-directional chessboard (Zig-Zag) strategy with $90^{\circ}$ rotation between contiguous layers, which formed a basket-weave microstructure. The scan track boundaries appear more heavily etched and darker. In the scan track interiors, smaller crystals 


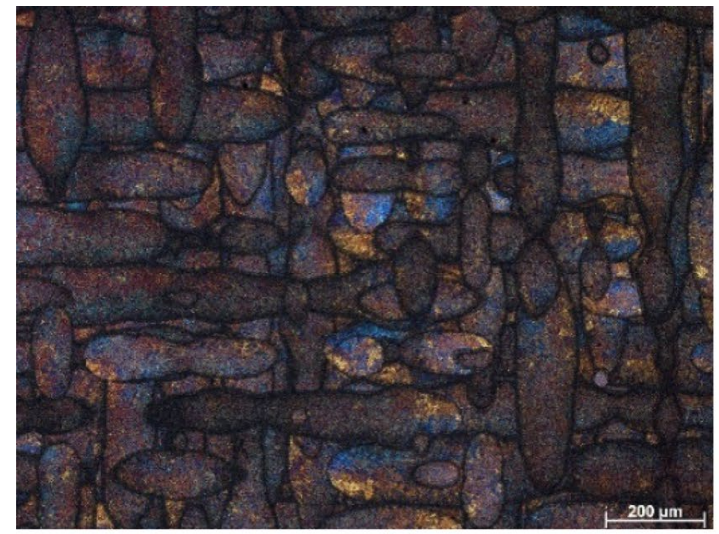

(a)

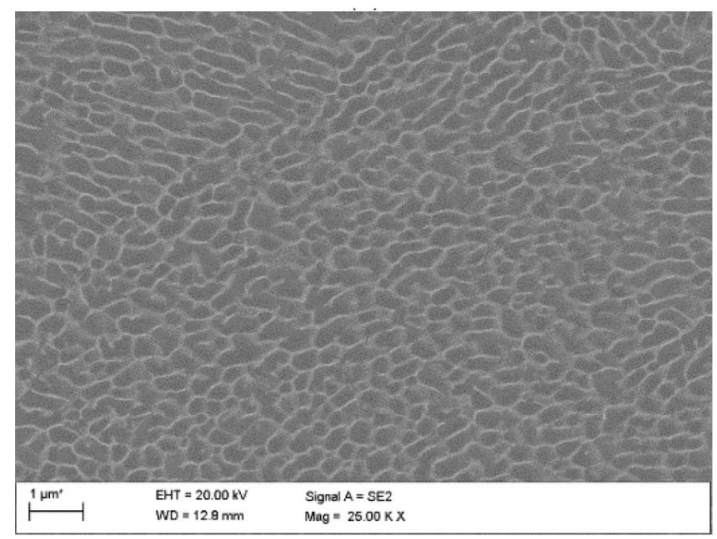

(c)

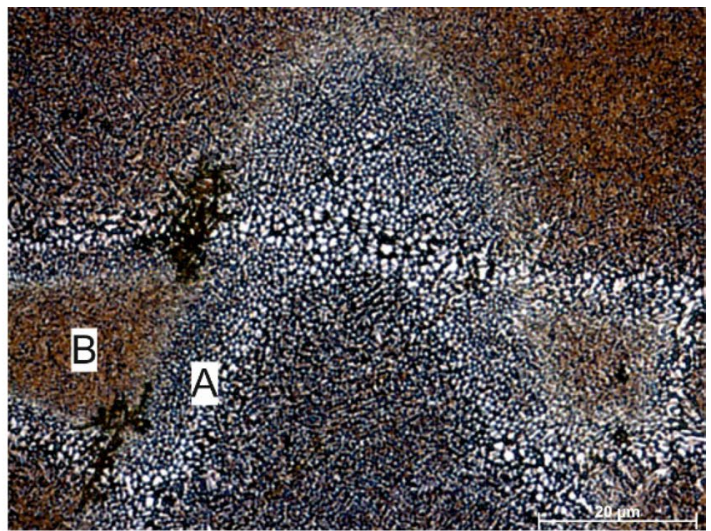

(b)
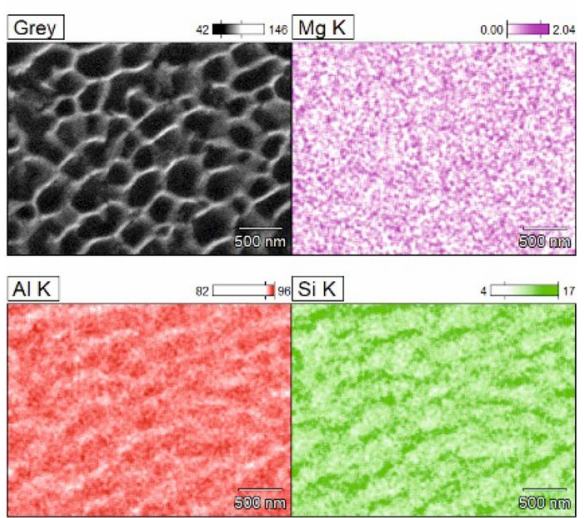

(d)

Fig. 3 Microstructure of the as-prepared SLM AlSi10Mg alloy S0 sample: a polarized light image; b bright field image; c SEM image; $\mathbf{d}$ elemental composition maps with corresponding SEM image

with diverse crystallographic orientations are also visible. This indicates a very small grain size owing to the rapid solidification.

Observations using the highest magnification limit of LM revealed additional details (Fig. 3b). A typical fish scale pattern induced by the Gaussian distribution shape of the laser beam was visible, and two distinct regions were observed in the microstructure: melt pool boundaries (A) and melt pool cores (B). The as-prepared SLM microstructure was inhomogeneous and contained coarser/elongated (located in the melt pool boundaries) and fine grains (located in the pool interiors), which is typical following laser powder bed fabrication. SEM analysis (Fig. 3c) allowed the identification of extremely fine cellular structures $(\sim 0.32 \mu \mathrm{m}$ in size). Such microstructures are associated with the high solidification rates achieved during the SLM process, which lead to the formation of the cellular structures $[25,26]$. The cell boundaries are brighter than the cell cores, which may indicate enrichment with heavier elements. This was confirmed by the SEM-EDX elemental composition maps, which indicated that the cellular structures were Si-rich (Fig. 3d).
Figure 4a shows the polarized light micrograph of the AlSi10Mg alloy $(\mathrm{C} 0)$ prepared by gravity casting. This technology yielded completely different microstructures compared with those obtained via AM processes. The as-cast AlSi10Mg alloy sample had a typical coarse-grained hypo-eutectic solidification microstructure (Fig. 4b) with a primary $\alpha-\mathrm{Al}$ matrix (light areas) and various types of dispersed micro-constituents in the interdendritic regions (dark areas). The dendrite arms define solidification cells about $30 \mu \mathrm{m}$ in size, surrounded by the eutectic Si particles that were several microns long and approx. $1 \mu \mathrm{m}$ wide. Three different phases were identified based on the metallographic (Fig. 4c) and EDX chemical composition microanalysis: $\alpha$-Al (alloy's matrix), $\mathrm{Mg}_{2} \mathrm{Si}$, and eutectic $\mathrm{Si}$. The average chemical composition of the identified phases was determined by EDX (Fig. 4d). 


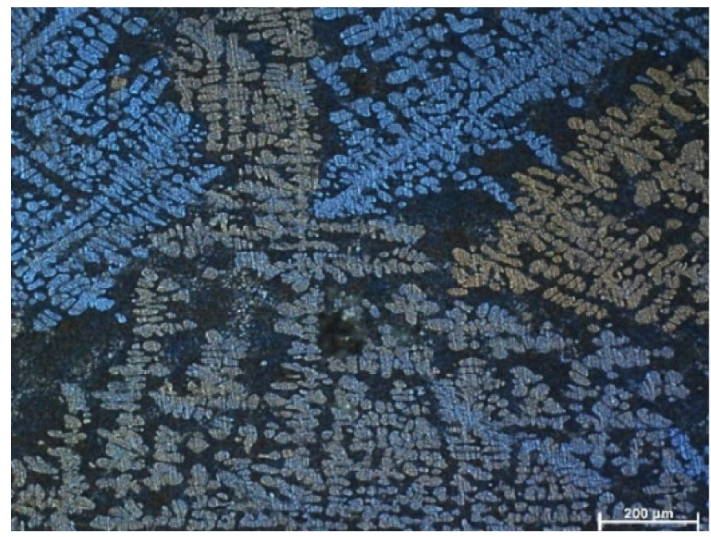

(a)

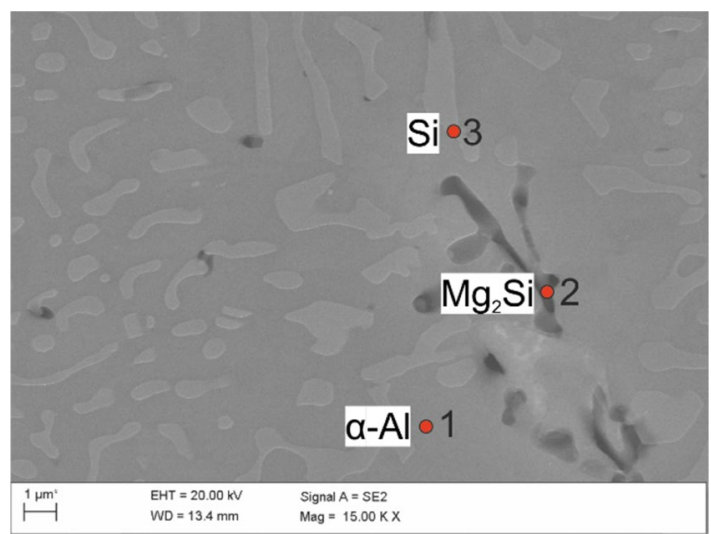

(c)

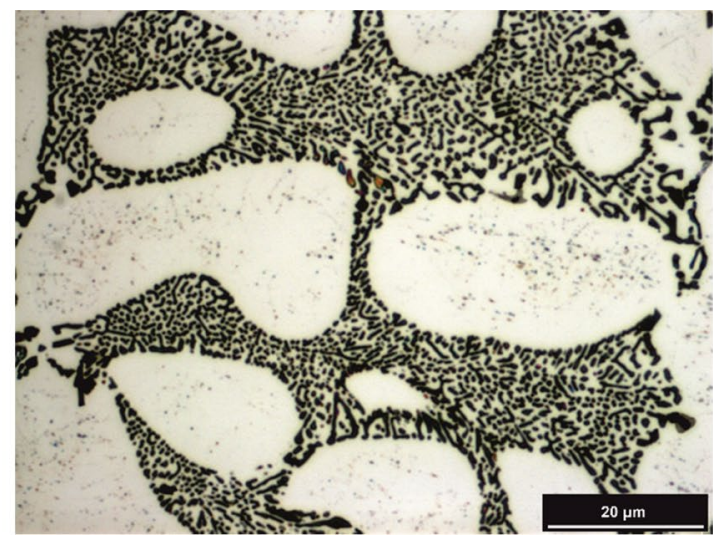

(b)

\begin{tabular}{cccc}
\hline Point & Element & At.\% & Wt.\% \\
\hline \multirow{2}{*}{1} & $\mathrm{Mg}$ & 1.10 & 1.00 \\
& $\mathrm{Al}$ & 97.50 & 97.60 \\
& $\mathrm{Si}$ & 1.40 & 1.40 \\
\multirow{2}{*}{2} & $\mathrm{Mg}$ & 10.40 & 9.50 \\
& $\mathrm{Al}$ & 82.80 & 83.50 \\
& $\mathrm{Si}$ & 6.80 & 7.00 \\
3 & $\mathrm{Mg}$ & 1.30 & 1.20 \\
& $\mathrm{Al}$ & 56.20 & 55.20 \\
& $\mathrm{Si}$ & 42.50 & 43.60 \\
\hline
\end{tabular}

(d)

Fig. 4 Microstructure of the as-cast AlSi10Mg alloy C0 sample: a polarized light image; $\mathbf{b}$ bright field image; $\mathbf{c}$ high-magnification SEM image of the eutectic area; $\mathbf{d}$ results of the pointwise chemical composition EDX microanalysis

\subsection{Microstructure after heat treatment}

\subsubsection{SLM + solution treatment (S1 sample)}

The heat treatment performed at $500{ }^{\circ} \mathrm{C}$ for $1 \mathrm{~h}$ caused a nearly complete breakdown of the arrangement typical for SLM technology. The microstructure transformed from a basket-weave to a more uniform structure. However, in the polarized light micrograph (Fig. 5a), some remaining features associated with the melt pool boundaries were still visible, and some areas reflected different light intensities, thus indicating their random crystallographic orientation.

Images captured at the highest magnification limit of the LM showed partially maintained "fish scale" features (Fig. 5b). The microstructure became coarser, and Si formed randomly distributed particles in the aluminum matrix, rather than comprising a hard "shell" around $\alpha-\mathrm{Al}$ grain boundaries (Fig. 3b).

Figure $5 \mathrm{c}$ shows the morphology and distribution of the Si particles at higher magnification. After the heat treatment, the Si agglomeration at the melt pool boundaries did not completely disappear. The preferential growth of Si particles at the melt pool boundaries was observed because these regions were remelted multiple times during SLM since they lie at the overlap of two hatches [27]. The vast majority of Si particles appeared to be irregular in shape, and their sizes ranged from 0.05 to $3 \mu \mathrm{m}$. This size of Si particles is typical for the applied heat treatment conditions [28, 29].

To examine the $\mathrm{Al}, \mathrm{Si}$, and $\mathrm{Mg}$ elemental distribution in the S1 sample in greater detail, EDX analysis was performed. Images obtained using secondary electrons and the corresponding $\mathrm{Al}, \mathrm{Si}$, and $\mathrm{Mg}$ elemental distribution maps are shown in Fig. 5d. According to EDX mapping, Al mainly covers the sample matrix, while Si segregates at the remaining melt pool boundaries and inside randomly distributed particles. 


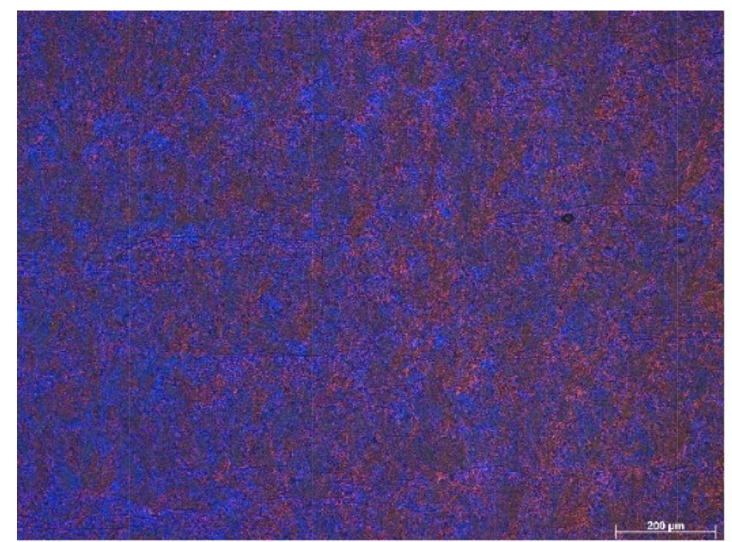

(a)

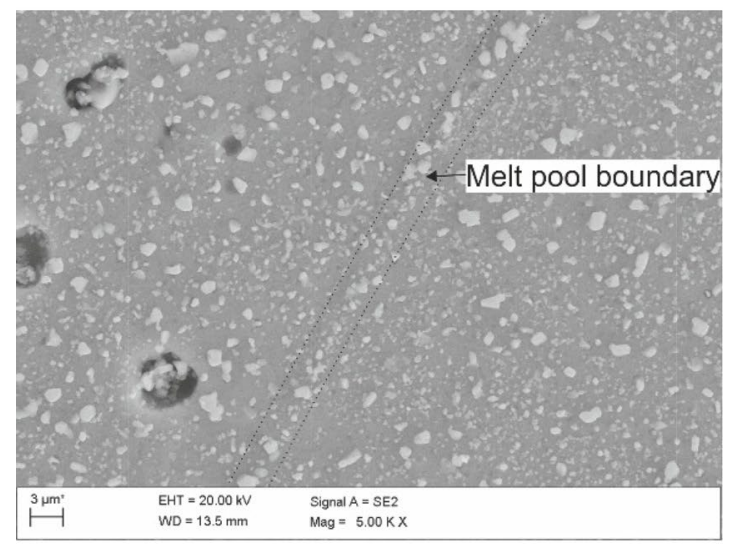

(c)

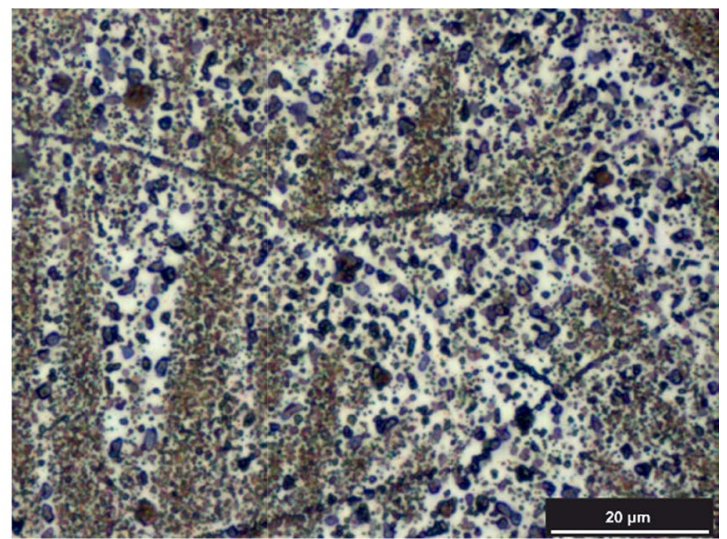

(b)
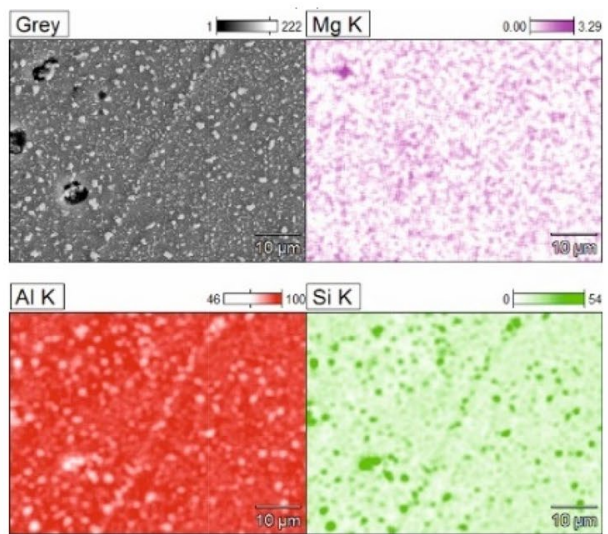

(d)

Fig. 5 Microstructure of the S1 sample: a polarized light image; b bright field image; $\mathbf{c}$ high-magnification SEM image; d elemental composition maps with corresponding SEM image

\subsubsection{SLM + low-temperature annealing ( $S 2$ sample)}

Figure 6 shows the microstructure of the investigated alloy after low-temperature annealing. This heat treatment did not cause significant changes in the macrostructure, i.e., the solidified melt pools and laser scan tracks typical of AM alloys were still present (Fig. 6a). Similar to the as-built sample, the scan track boundaries were heavily etched and appeared darker. Some variations in the crystallographic orientation were also visible in the scan track interiors. This indicated that a relatively small grain size was maintained after low-temperature annealing.

Observations at the highest magnification limit of LM revealed fully maintained "fish scale" microstructural features (Fig. 6b). Similar to the S0 sample, two distinct regions were distinguishable in the microstructure: melt pool boundaries (A) and melt pool cores (B). The cellular structures in the melt pool boundaries in this case were significantly larger than those observed in the as-built sample, making them easily noticeable. However, the melt pool cores were composed of ultra-fine cell structures that could not be easily identified using a light microscope.

Figure 6c shows a higher magnification SEM image of the $\mathrm{S} 2$ sample, revealing the microstructural evolution during low-temperature annealing. This heat treatment led to a complete breakdown of the eutectic network; however, the overall appearance of the cell structure was still recognizable. In general, the microstructure became coarser, and $\mathrm{Si}$ particles became larger after low-temperature annealing.

To investigate the chemistry of the $\mathrm{Al} / \mathrm{Si}$ interface in the S2 sample, EDX analysis was performed (Fig. 6d). The Si enrichment at the cell boundaries was clearly visible, as well as $\alpha$-Al over-saturation. Owing to the high solubility of magnesium in aluminum, $\mathrm{Mg}$ was is uniformly distributed in the alloy matrix.

\subsubsection{Casting + solution heat treatment (C1 sample)}

Figure 7 shows the microstructures observed by optical and scanning electron microscopy for the solution-treated cast 


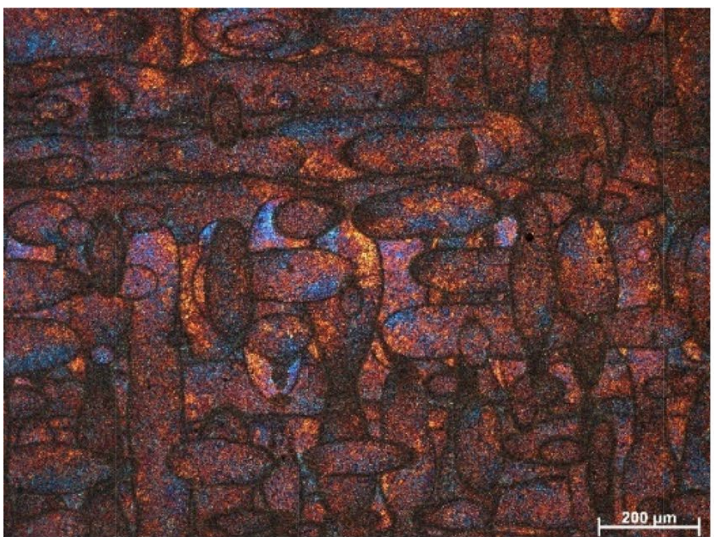

(a)

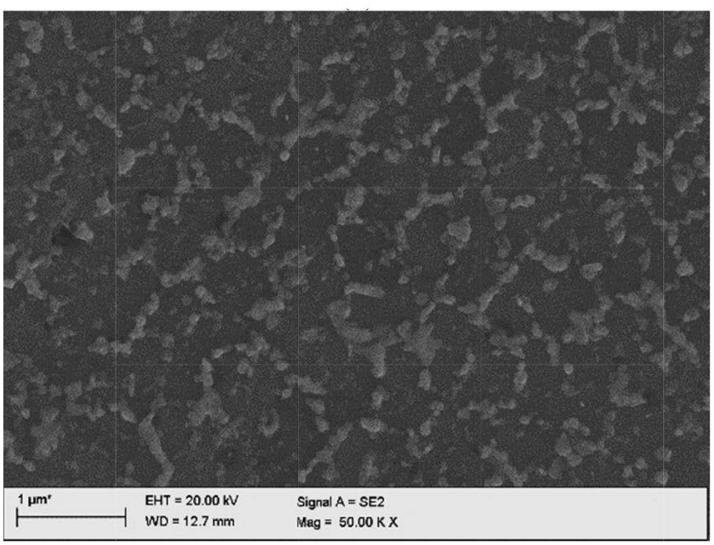

(c)

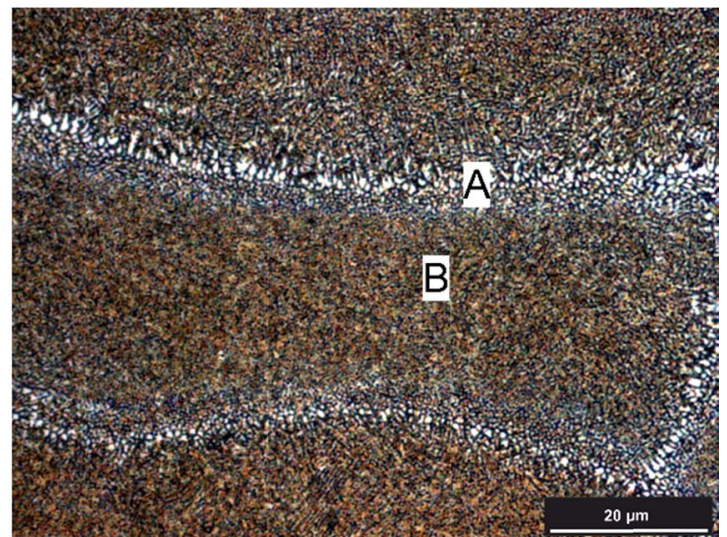

(b)
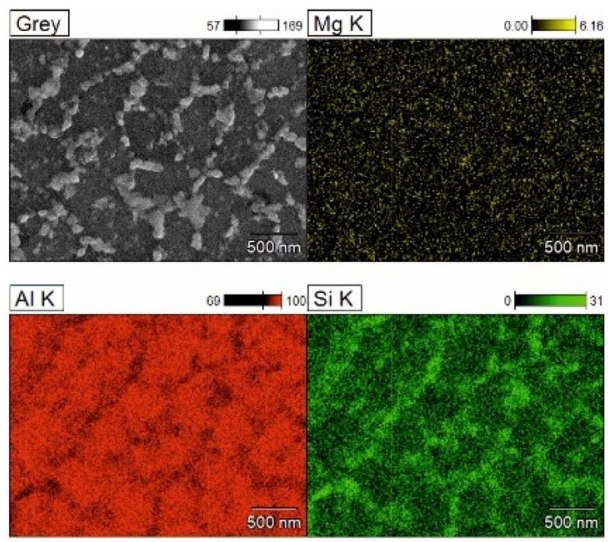

(d)

Fig. 6 Microstructure of the S2 sample: a polarized light image; b bright field image; $\mathbf{c}$ high-magnification SEM image; $\mathbf{d}$ elemental composition maps with corresponding SEM image

(C1) sample. The typical coarse-grained dendritic casting structure composed of primary $\alpha-\mathrm{Al}$ and eutectic phases was completely maintained (Fig. 7a). However, the morphology of eutectic Si particles changed slightly because of the diffusion processes (Fig. 7b). Specifically, they became fragmented, rounder, and coarser (Fig. 7c) compared with the as-cast state (Fig. 4b). SEM analysis and EDX elemental mapping confirmed the presence of $\alpha-\mathrm{Al}, \mathrm{Mg}_{2} \mathrm{Si}$, and eutectic Si phases (Fig. 7d).

\subsection{Microstructures after ECAP}

Figure 8 presents the optical micrographs showing the microstructural evolution of materials with increasing numbers of ECAP passes and different initial conditions. Each sample microstructure was examined at the cross-section plane.

After the first ECAP pass (Fig. 8a), the microstructure of cast alloy (C1-1 sample) comprised slightly elongated primary $\alpha-\mathrm{Al}$ cells, which were similar in size to those observed in sample $\mathrm{C} 1$. The effect of ECAP was more evident after the second pass (C2-2 sample; Fig. 8b). The dendritic structure and microstructural constituents became significantly elongated and pancaked, so the initial dendritic structure (Fig. 6b) transformed into a band-like structure.

The microstructure of the SLM alloy (S1-1 sample) after the first ECAP pass is shown in Fig. 8c. The analyzed representative area consists of numerous micro-metric cellular structures localized between parallel deformation bands approx. 70-90 $\mu \mathrm{m}$ wide (white arrows). This microstructure evolved progressively after the subsequent ECAP pass (Fig. 8d). The additional deformations increased the number of parallel deformation bands. Additionally, an array of not well-defined cell structure boundaries was observed (yellow arrows).

The images in Fig. 8e,f show the novel microstructures after the first (S2-1 sample) and second (S2-2 sample) ECAP pass, respectively. It is clear from comparing Fig. 6a (S2 sample) and Fig. 8e (S2-1 sample) that a basket-weave microstructure evolved during ECAP. Surprisingly, after the first pass, the resulting microstructure was a combination of stacked "fish scale" patterns and parallel deformation bands 


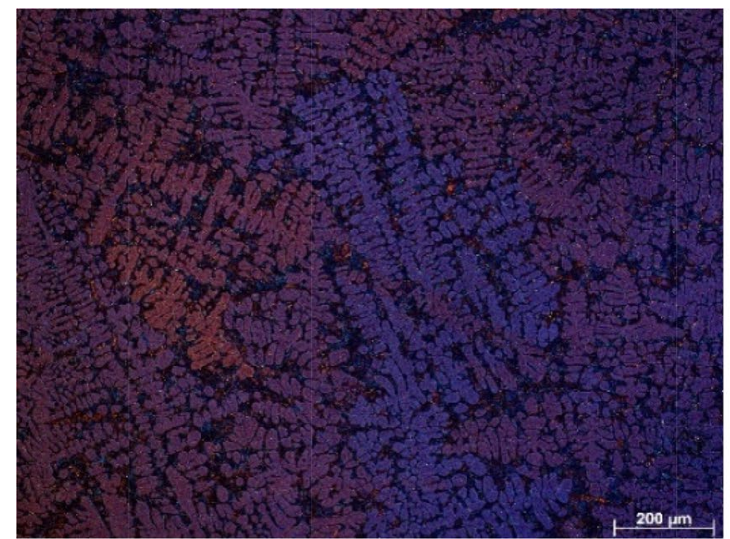

(a)

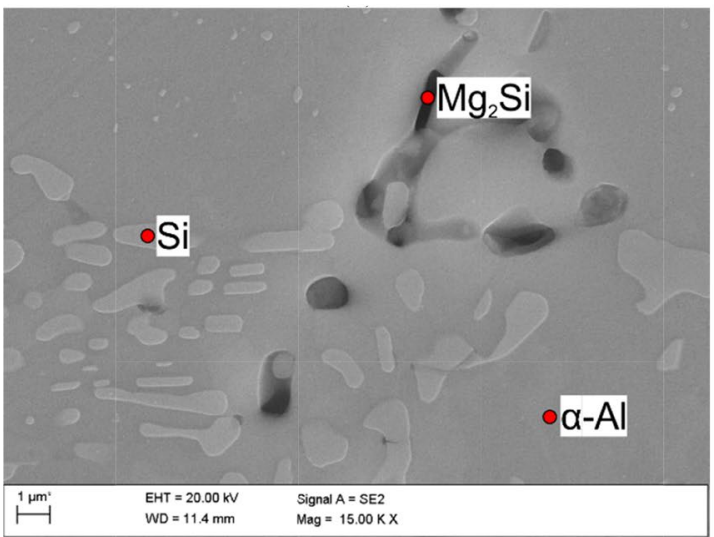

(c)

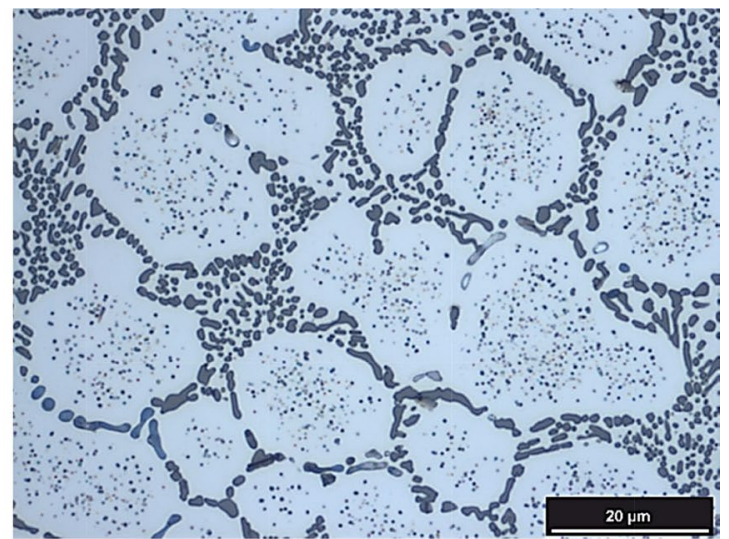

(b)
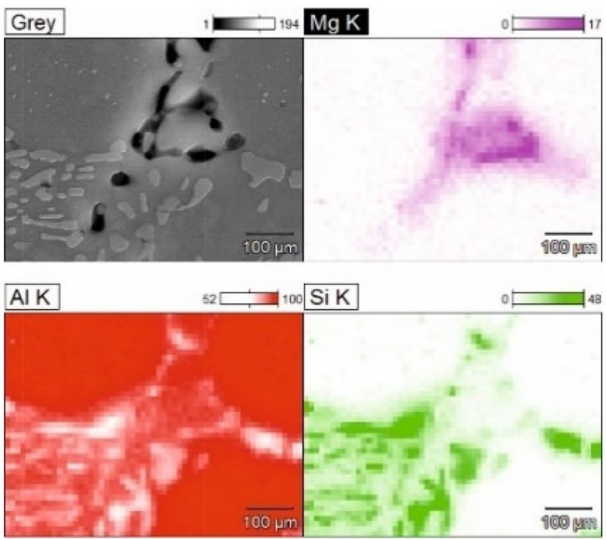

(d)

Fig. 7 Microstructure of the C1 sample: a polarized light image; b bright field image; $\mathbf{c}$ high-magnification SEM image; $\mathbf{d}$ elemental composition maps with corresponding SEM image

approx. $70 \mu \mathrm{m}$ wide. After the second pass, more significant changes to the microstructure occurred (Fig. 8f). The observed "fish scale" patterns became heavily pancaked and elongated along the transverse direction (TD).

\subsection{Mechanical properties}

Table 5 summarizes the Vickers microhardness results (averages), measured on the ND-TD plane across the sample diameter, and Fig. 9 shows these values plotted as a function of the number of ECAP passes. It is clear from Table 5 that the as-cast (C0) sample had the lowest microhardness ( 68 $\mathrm{HV}$ ), and the measured microhardness decreased by about $10 \%(\sim 61 \mathrm{HV})$ after applying the solution heat treatment (C1 sample). In contrast, the SLM (S0) sample had a very high microhardness $(\sim 135 \mathrm{HV})$, which was consistent with a previous report [30]. The measured microhardness decreased by about $50 \%$ after the solution heat treatment ( 1 1 sample) and by about $25 \%$ after low-temperature annealing.

A significant microhardness enhancement occurred after ECAP as a result of microstructural refinement (Fig. 9). The
C1 sample hardness increased gradually from 61 to $93.2 \mathrm{HV}$ after three ECAP passes, and then the hardness decreased slightly to $91.7 \mathrm{HV}$. A similar hardening behavior was observed for the S1 sample; the microhardness increased rapidly after the first ECAP pass, from 66.5 to $96.8 \mathrm{HV}$. Further microhardness enhancement occurred following subsequent ECAP passes, and after four ECAP passes, the average microhardness reached 104.1 HV. However, the S2 sample showed distinct hardening behavior. There was a rapid increase in microhardness, from 101.2 to $137.2 \mathrm{HV}$ after the first pass, which was followed by a slight decrease to $135.1 \mathrm{HV}$ after the second pass. The mechanical properties drop after a certain number of ECAP passes can be related to microstructural changes. After ECAP, the degree of heterogeneity decreased, thus the strengthening produced by the incompatibility between aluminium matrix and $\mathrm{Si}$ particles. Similar observations-mechanical properties drop after a certain number of ECAP passes have been observed in this study [31].

The different strain hardening rates of the $\mathrm{C} 1, \mathrm{~S} 1$, and $\mathrm{S} 2$ samples was attributed to their unique microstructures, 
Fig. 8 Microstructures of the AlSi10Mg alloy samples after ECAP: a C1-1; b C1-2; c S1-1; d S1-2; e S2-1; f S2-2

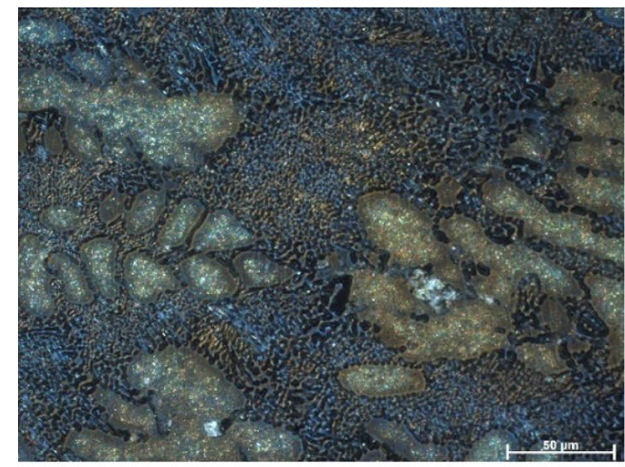

(a)

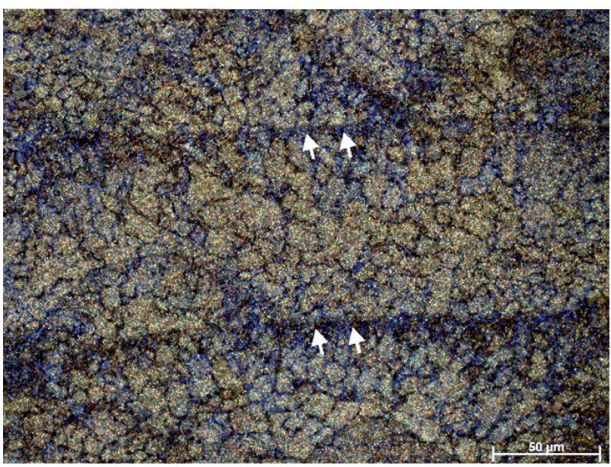

(c)

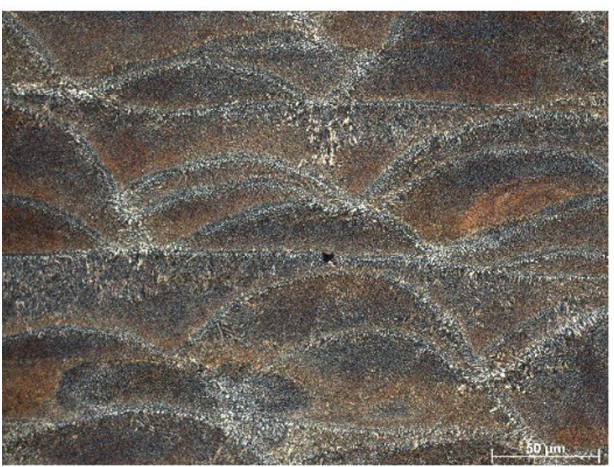

(e)

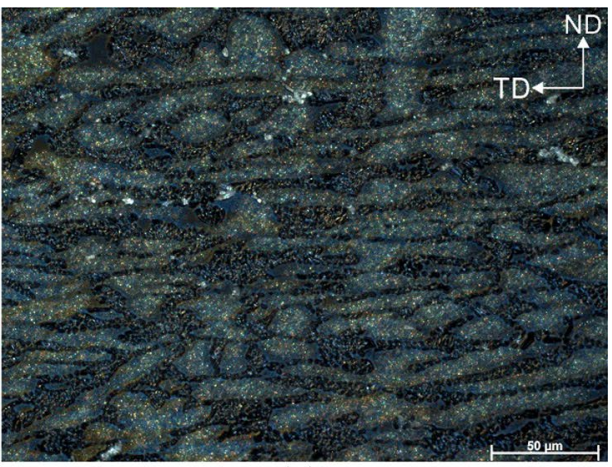

(b)

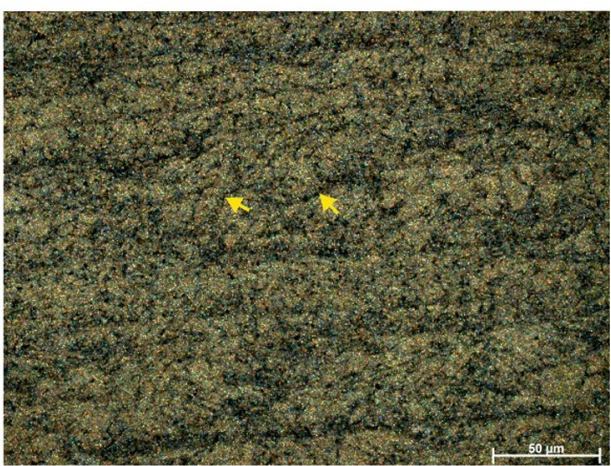

(d)

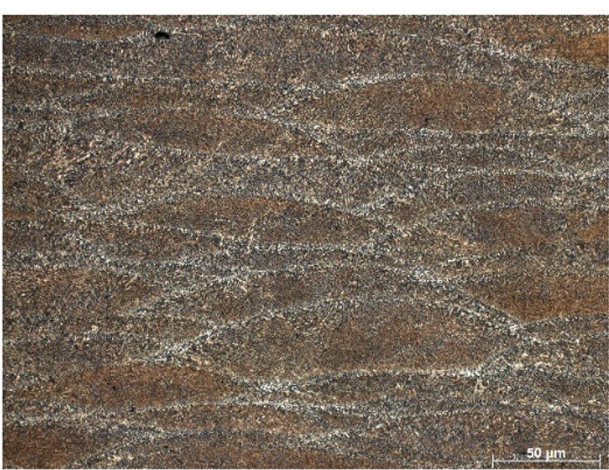

(f) since the S2 sample had a partially maintained heterogeneous partial-cellular microstructure prior to ECAP. During plastic deformation, large local strain gradients existing between the cell cores and the Si particles led to much higher accumulations of geometrically necessary dislocations (GNDs), which were responsible for the faster grain refinement and resulting mechanical properties enhancement. However, the role of the generated strain gradient (partial-cellular microstructure) in the strain hardening behavior of the AlSi10Mg alloy requires further clarification via electron microscopy.

Figure 10 shows the compression engineering stress-engineering strain curves for the SLM, low-temperature annealed SLM, and SLM+ECAP-processed samples. Table 6 summarizes their yield strengths, ultimate compressive strengths, and stain to failures.
It was clear that the as-built (S0) sample exhibited the highest ultimate compressive strength and had excellent yield strength (794 and $370 \mathrm{MPa}$, respectively). Low-temperature annealing resulted in partial disappearance of the heterogeneous microstructure, and reduction of the residual stress decreased the yield strength and the ultimate compressive strength to 264 and $650 \mathrm{MPa}$, respectively. However, along with the reduction in yield strength, a significant increase in ductility increase was obtained. As expected, ECAP processing further enhanced the mechanical properties of the AlSi10Mg alloy. After the first ECAP pass (S2-1 sample), the yield strength and ultimate compressive strength increased to 315 and $685 \mathrm{MPa}$, respectively. After the second pass (S2-2 sample), the yield strength increased to $382 \mathrm{MPa}$, but this improvement was achieved at the expense of ultimate compressive strength and ductility. In 
Table 5 Vickers microhardness measurements of the initial and the ECAP-processed AlSi10Mg alloy samples

\begin{tabular}{llc}
\hline Sample ID & & $\begin{array}{l}\text { Microhard- } \\
\text { ness (aver- } \\
\text { age) }\end{array}$ \\
\hline S0 & SLM & 135.4 \\
S1 & SLM+ solution treatment & 66.5 \\
S2 & SLM+ low-temperature annealing & 101.2 \\
& 300 ${ }^{\circ}$ C 8 min & \\
S1-1 & 1 ECAP pass & 96.8 \\
S1-2 & 2 ECAP passes & 103.1 \\
S1-3 & 3 ECAP passes & 103.9 \\
S1-4 & 4 ECAP passes & 104.1 \\
S2-1 & 1 ECAP pass & 137.2 \\
S2-2 & 2 ECAP passes & 135.1 \\
C0 & As-cast & 68.1 \\
C1 & As-cast + solution treatment & 61.0 \\
C1-1 & 1 ECAP pass & 87.0 \\
C1-2 & 2 ECAP passes & 89.5 \\
C1-3 & 3 ECAP passes & 93.2 \\
C1-4 & 4 ECAP passes & 91.7 \\
\hline
\end{tabular}

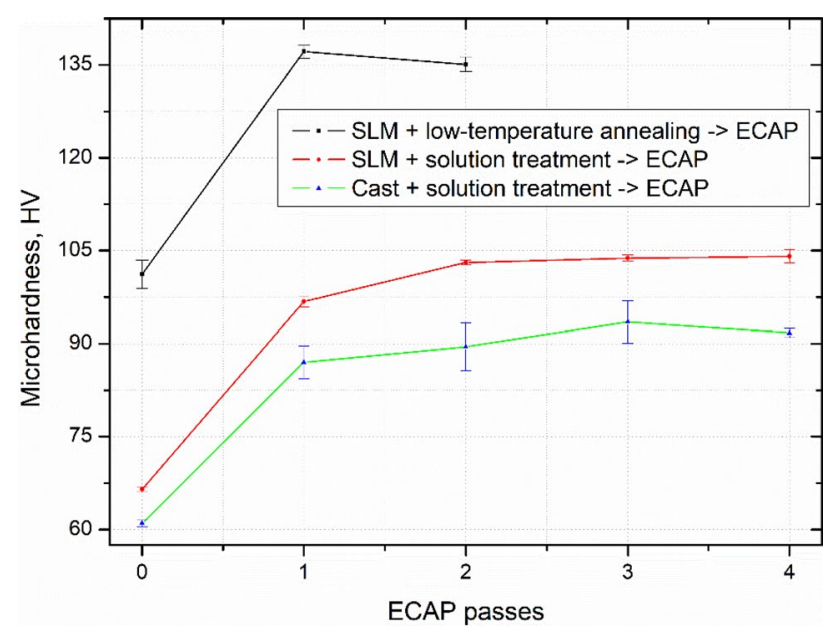

Fig. 9 Hardness values as a function of ECAP passes

this case, the ultimate compressive strength (675 MPa) was registered at a strain value of $48 \%$.

\subsection{XRD analysis}

XRD analysis was additionally performed to support the microstructural results. Figure 11 shows the X-ray diffraction profiles of the AlSi10Mg alloy samples in different conditions. The main identified reflections corresponded to aluminum (111), (200), (220), (311), (222); Si (111), (311); and $\mathrm{Mg}_{2} \mathrm{Si}$ (220) crystalline phases. The Si peaks of the solution heat-treated samples $(\mathrm{C} 1, \mathrm{C} 1-2)$ and SLM

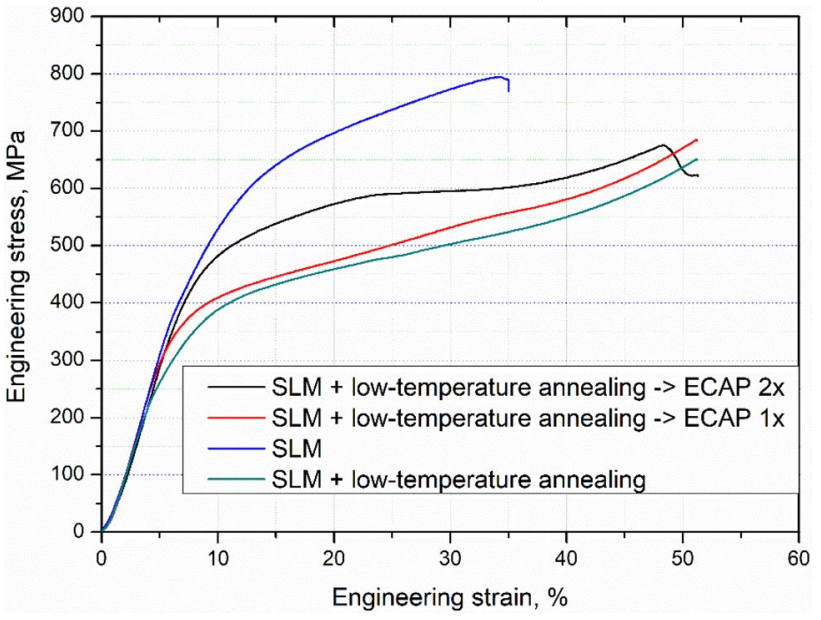

Fig. 10 Comparison of the engineering stress-engineering strain curves from compressive tests for the investigated SLM AlSi10Mg alloys in various conditions

Table 6 Ultimate compressive strength, yield strength, and strain to failure of the SLM samples

\begin{tabular}{llll}
\hline Sample ID & $\begin{array}{l}\text { Strain to } \\
\text { failure (\%) }\end{array}$ & $\begin{array}{l}\text { Yield strength } \\
\text { (MPa) }\end{array}$ & $\begin{array}{l}\text { Ultimate compres- } \\
\text { sive strength } \\
\text { (MPa) }\end{array}$ \\
\hline S0 & 34 & 378 & 794 \\
S2 & $*$ & 264 & 650 \\
S2-1 & $*$ & 315 & 685 \\
S2-2 & 48 & 382 & 675 \\
\hline
\end{tabular}

*The compressive tests were conducted up to $51 \%$ deformation

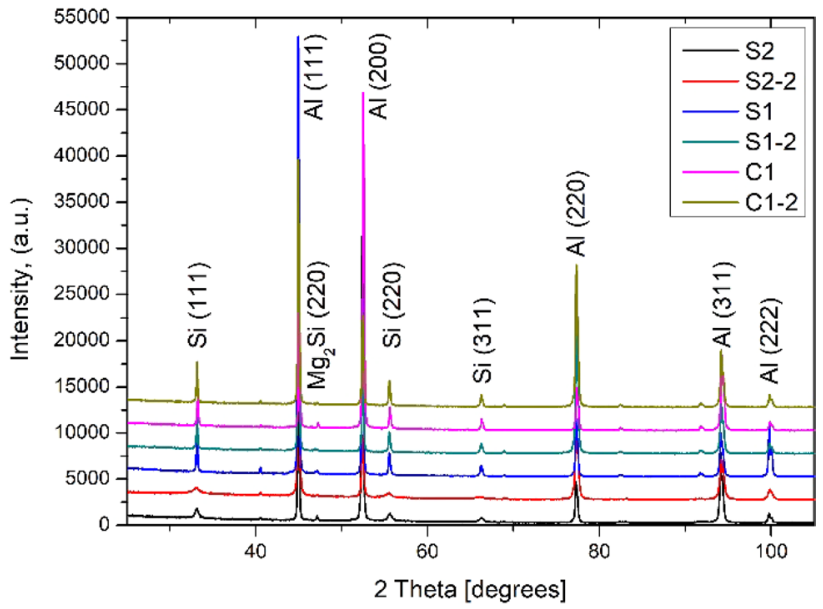

Fig. 11 XRD patterns of the AlSi10Mg alloys in different conditions

samples (S1, S1-2) had higher intensities than those of asbuilt or annealed samples (S2, S2-2). This is because, in the $\mathrm{S} 2$ condition, the alloy's matrix was supersaturated with $\mathrm{Si}$. 
However, during the solution heat treatment, Si tended to diffuse, thus significantly decreasing the Si solid solubility [32] and increasing the peak intensity [33].

$\mathrm{X}$-ray diffraction peak profile analysis was conducted to evaluate the microstructural changes caused by ECAP deformation. Equation (4) was used to calculate the lattice strain and the crystallite size,

$B \cos \theta=\left[\frac{0.9 \lambda}{D}\right]+[4 \varepsilon \sin \theta]$

where $\lambda$ is the $\mathrm{X}$-ray wavelength, $\theta$ is the Bragg angle, $B$ is the line broadening, and $\varepsilon$ is the root mean square of the microstrain. These results are summarized in Table 7 .

The solution-treated samples processed by ECAP had the lowest dislocation densities $\left(1.57-5.02 \times 10^{14} \mathrm{~m}^{-2}\right)$. The lower dislocation density may arise from their initial microstructure. The large, dispersed Si particles observed in the solution-treated condition represented weaker obstacles for dislocations, whereas smaller particles (e.g., observed in the $\mathrm{S} 2$ condition) could serve as additional obstacles for mobile dislocations in the Al matrix. Additionally, considering strain gradient plasticity theory [34], a higher density of GNDs can accumulate near $\mathrm{Al} / \mathrm{Si}$ interfaces in the $\mathrm{S} 2$ sample [35] during the severe plastic deformation, which increases strain hardening and improves mechanical properties [36]. The calculated dislocation density for the S2-2 sample $\left(1.23 \times 10^{15} \mathrm{~m}^{-2}\right)$ was slightly lower than the recently reported dislocation density $\left(5.11 \times 10^{14} \mathrm{~m}^{-2}\right)$ for the SLM AlSi10Mg alloy subjected to high-pressure torsion [10]. The values obtained from XRD analysis for the solution-treated, ECAP-processed samples were very close to the value reported by Cardoso et al. [37] for as-cast Al-10wt.\%Si $\left(4.5 \times 10^{14} \mathrm{~m}^{-2}\right)$, and by Zribi et al. [38] for as-cast Al-7wt. \% Si after ECAP $\left(1.9 \times 10^{14} \mathrm{~m}^{-2}\right)$.

\section{Discussion}

To date, many attempts have been made to increase the mechanical properties of cast Al-Si alloys [35, 37, 39, 40]. Researchers attribute the high mechanical strength of this alloy system to the enhanced grain refinement caused by the accumulation of geometrically necessary dislocations in the strain gradient fields [35]. According to strain gradient plasticity theory, GNDs will accumulate in the alloy matrix surrounding large, nondeformable particles. This generates strong back-stresses [38], which develop when dislocations are a few nanometers away from $\mathrm{Si}$ particles [41].

As is shown, Fig. 7b, the $\mathrm{C} 1$ sample microstructure contained relatively large and brittle $\mathrm{Si}$ particles arranged in a solidification cellular distribution between the original Al dendrites. This microstructure evolved during severe plastic deformation; Si particles became fragmented, so the volume fraction of nondeformable particles in the microstructure increased. Cho et al. [42] demonstrated that such particles formed by severe plastic deformation play a role as dislocation multiplication sites. It is widely reported that during plastic deformation, the strain incompatibility between these hard Si particles and the soft $\alpha-\mathrm{Al}$ matrix is accommodated by the generation of GNDs, which provide a strong driving force for substructure formation [37-40]. Considering that the density of geometrically necessary dislocations $\left(\rho_{\mathrm{GND}}\right)$ is proportional to the strain gradient (i.e., the variation of plastic strain over the microstructural length $(\lambda)$ for which the gradient is created; Eq. 5) [43] it is possible to predict the density of GNDs in the C1-2 sample.

$\rho_{\mathrm{GND}}=8 \varepsilon / 3 b \lambda$

The aforementioned spacing between the near-continuous Si cellular network and bands in the as-cast solutiontreated AlSi10Mg alloy was approx. $20 \mu \mathrm{m}$, which corresponds to $\rho_{\mathrm{GND}}=5.67 \times 10^{14} \mathrm{~m}^{-2}$, which is consistent with a previous study [39].

In contrast to the solution-treated cast sample $(\mathrm{C} 1)$, the SLM sample (S1) had a completely different microstructure, composed of uniformly distributed Si particles approximately $0.4 \mu \mathrm{m}$ in diameter. Therefore, it can be assumed that to achieve compatible deformation, Orowan loops can also form and be stored in the grains when dislocations attempt to bypass the precipitates. Similarly, GND accumulation is expected. In this condition, the measured mean spacing between large nondeformable Si particles was approx. 2.1 $\mu \mathrm{m}$. Therefore, using Eq. (5), we obtain
Table 7 Evolution of microstructural parameters

\begin{tabular}{llllll}
\hline Sample ID & Lattice microstrain, $\varepsilon$ & $\begin{array}{l}\text { Crystalline size, } \\
D(\mathrm{~nm})\end{array}$ & $\rho_{\mathrm{d}}\left(\mathrm{m}^{-2}\right)$ & $\rho_{\mathrm{s}}\left(\mathrm{m}^{-2}\right)$ & $\rho\left(\mathrm{m}^{-2}\right)$ \\
\hline S1-2 & $3.03 \times 10^{-3}$ & 39 & $1.90 \times 10^{15}$ & $1.33 \times 10^{14}$ & $5.02 \times 10^{14}$ \\
S2-2 & $6.50 \times 10^{-3}$ & 32 & $2.95 \times 10^{15}$ & $5.16 \times 10^{14}$ & $1.23 \times 10^{15}$ \\
C1-2 & $1.11 \times 10^{-3}$ & 43 & $1.64 \times 10^{15}$ & $1.50 \times 10^{13}$ & $1.57 \times 10^{14}$ \\
\hline
\end{tabular}

$\rho_{s}$ dislocation density due to lattice microstrain; $\rho_{d}$ dislocation density due to size effect; $\rho$ total dislocation density 
$\rho_{\mathrm{GND}}=5.40 \times 10^{15} \mathrm{~m}^{-2}$, which is verified by the XRD results since the overall dislocation density in the S1-2 was higher than in the C1-2 sample.

After low-temperature annealing, the overall appearance of the heterogeneous cellular structure was partially maintained; however, the $\lambda$ microstructural length grew slightly from $0.326 \mu \mathrm{m}$ (S0 sample) to $\sim 0.446 \mu \mathrm{m}$ (S2 sample) (see Fig. 12), which leads to $\rho_{\mathrm{GND}}=1.27 \times 10^{16} \mathrm{~m}^{-2}$ or $\rho_{\mathrm{GND}}=2.54 \times 10^{16} \mathrm{~m}^{-2}$ after 1 or 2 ECAP passes, respectively. Indeed, the density of GNDs increased with increasing strain accumulation. The GND density of the S2-1 sample $\left(\rho_{\mathrm{GND}}=6.44 \times 10^{14} \mathrm{~m}^{-2}\right)$ calculated using ATEX software, was lower than that of the S2-2 sample $\left(\rho_{\mathrm{GND}}=7.20 \times 10^{14} \mathrm{~m}^{-2}\right)$ (see Fig. 13). These values are also much lower than those estimated above for the GND density. This can be explained because during ECAP processing, dislocation multiplication is balanced by the dislocation annihilation [45]. Additionally, in the later stages of plastic deformation, GNDs with the opposite sign might neutralize, leading to an exhaustion of dislocations. Finally, with an increase in strain accumulation, the degree of heterogeneity decreases [44] leading to a decrease in the GND density.

It is clear that GNDs have a crucial influence on the mechanical properties of the AlSi10Mg alloy after ECAP; therefore, it is worth investigating the substructure development because GNDs are believed to be responsible for faster grain refinement. Therefore, we conducted a more detailed observation of the S2-2 sample using TEM. Figure 14 shows a typical bright field TEM image taken from the horizontal cross-section. On this micrograph, many cellular structures (average size $\approx 0.3 \mu \mathrm{m}$ ) are visible. This image clearly shows that cell boundaries are composed of the refined nanoscale Si precipitates (white arrows).

Closer observation of areas 1 and 2 under higher magnification (Fig. 15) indicated that after two ECAP passes, a submicron-sized polycrystalline structure developed. The high-density dislocations introduced into the AlSi $10 \mathrm{Mg}$ alloy via room temperature ECAP produced strong local strain contrasts in these TEM micrographs. These dislocations are visible at the cell boundaries and around Si particles. This suggests that the Si particles served as dislocation multiplication sites during severe plastic deformation. The microstructure became more refined, while sub-grains (40-50 nm in size) appeared frequently in the bright field TEM micrographs (Fig. 15b, d). The average sub-grain size, measured from four different dark field images, was approx. $150 \mathrm{~nm}$. This demonstrated that the GNDs generated during plastic deformation played a significant role in the grain refinement of the AlSi10Mg alloy, since the most frequently reported grain sizes for similar alloys after two ECAP passes are 600-800 nm [37].

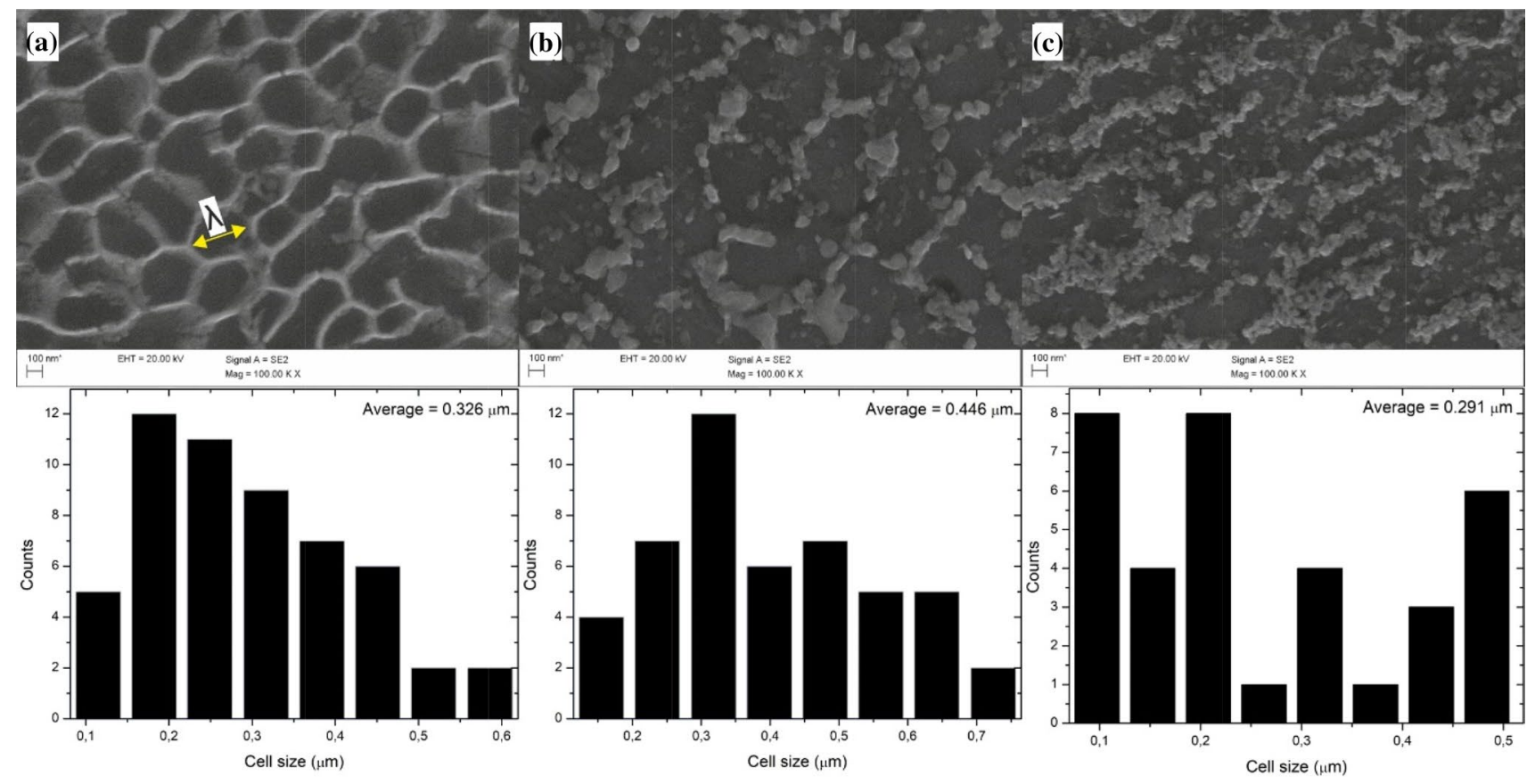

Fig. 12 Evolution of cell structures in the SLM AlSi10Mg alloys: a as-built; b S2 condition; c S2-2 condition (two ECAP passes), and the corresponding cell size distribution histograms 

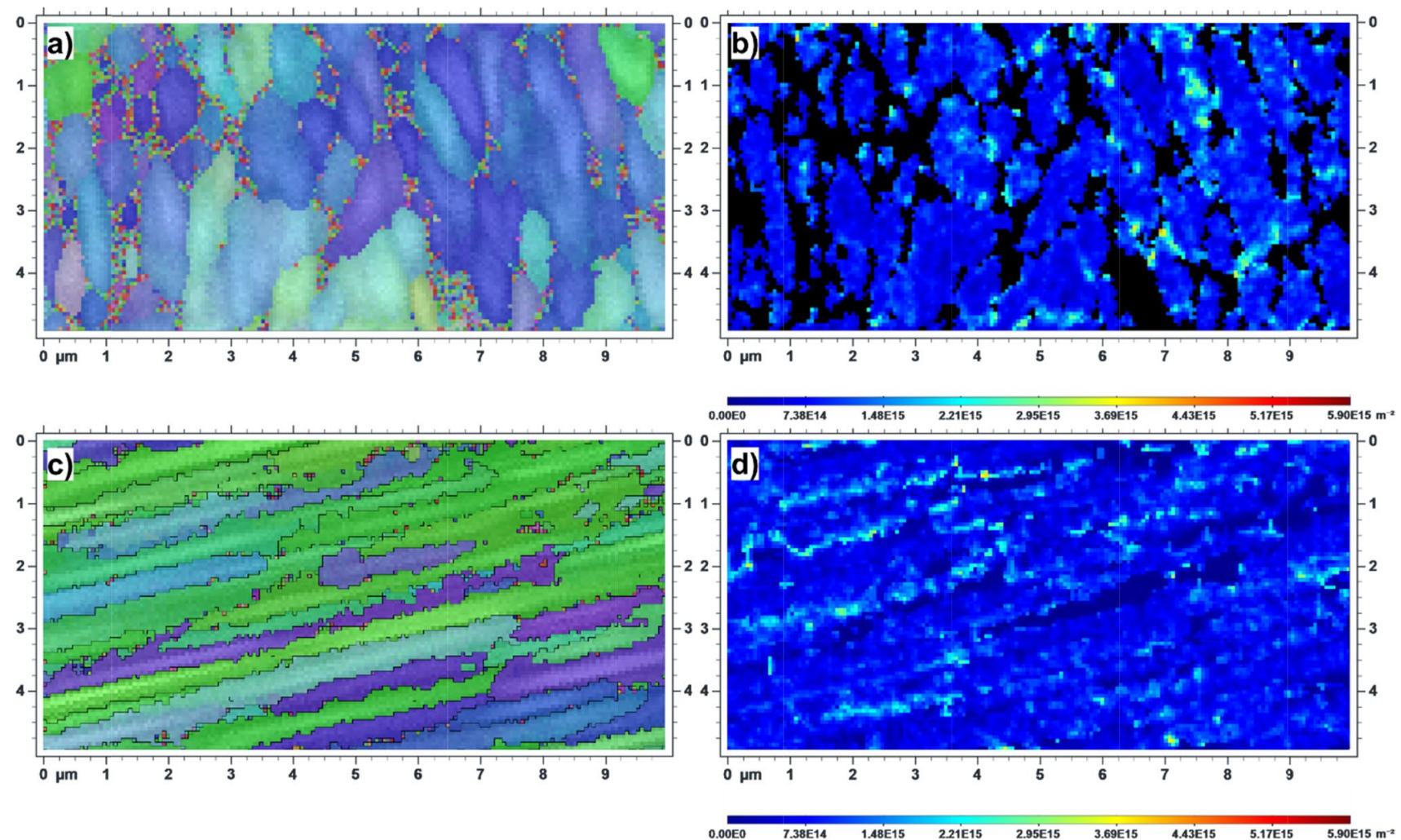

Fig. 13 a, $\mathbf{c}$ IPF images; $\mathbf{b}, \mathbf{d}$ GND dislocation density mapping calculated from KAM images of S2-1 and S2-2 samples

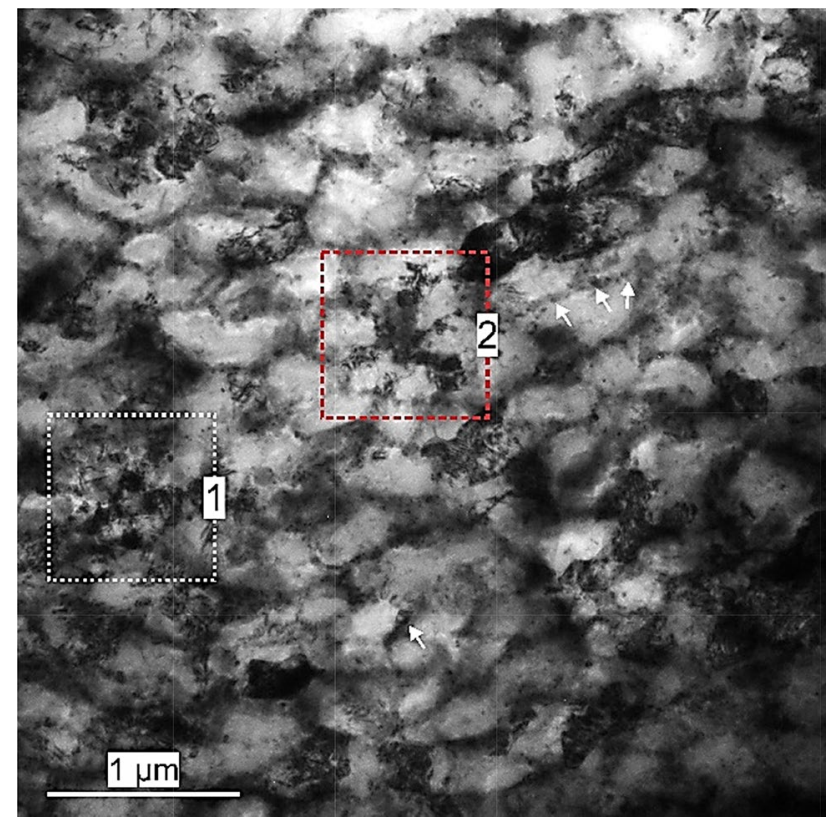

Fig. 14 TEM micrograph of the SLM and two-ECAP pass sample (S2-2)

\section{Conclusions}

In this study, the effects of heat treatment and a novel combination of heat treatment combined with equal channel angular pressing on the microstructural evolution and mechanical properties of as-cast and SLM-fabricated AlSi10Mg alloys were investigated. The major conclusions from this work are summarized as follows:

- For all of the processed samples, the hardness increased with strain accumulation. The high hardness exhibited by SLM and ECAP-processed alloys were far beyond what can be achieved in conventionally deformed cast Al-Si alloys, or even cast ECAP-treated Al-Si alloys.

- The highest yield strength (382 MPa) was obtained in the sample subjected to low-temperature annealing and two ECAP passes. Dislocation strengthening and grain refinement decreased the average grain size to $\sim 150 \mathrm{~nm}$ and represented the most dominant strengthening mechanisms.

- The initial microstructure had an influence on the mechanical properties of the AlSi10Mg alloys subjected to severe plastic deformation owing to the outstanding hardening capability of the partial-cellular microstructure. Therefore, further research should be directed towards determining the effects of heat treatment and initial microstructure heterogeneity prior to ECAP on the work hardening and mechanical properties of AlSi10Mg alloys. 
Fig. 15 Bright and dark field TEM micrographs of the SLM AlSi10Mg alloy subjected to two ECAP passes: a, b area 1; c, $\mathbf{d}$ area 2
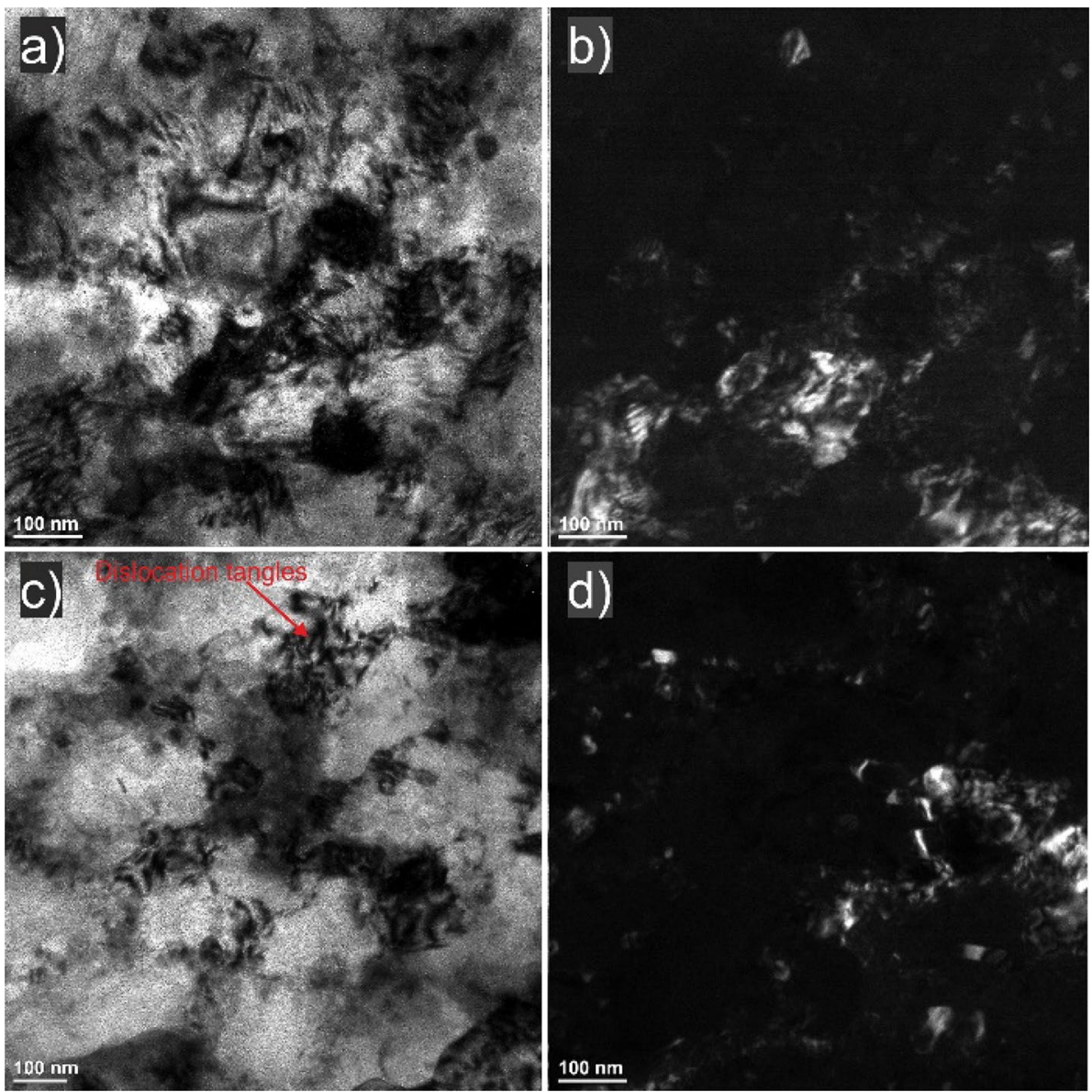

Author contribution All authors contributed to the study conception and design. Material preparation, data collection and analysis were performed by Przemysław Snopiński, Marusz Król, Jana Petrů, Tomasz Mikuszewski, Pagáč, Tomasz Tański and Jiří Hajnyš, The first draft of the manuscript was written by Przemysław Snopiński and all authors commented on previous versions of the manuscript. All authors read and approved the final manuscript.

Funding This work was partially financed by the Ministry of Science and Higher Education of Poland as the statutory financial grant of the Faculty of Mechanical Engineering SUT. This article has been completed in association with project Innovative and additive manufacturing technology - new technological solutions for 3D printing of metals and composite materials, reg. no. 319 CZ.02.1.01/0.0/0.0/17_049/000 8407 financed by Structural Funds of the European Union.

Availability of data and material The data that support the findings of this study are available from the corresponding author, [Przemysław Snopiński], upon reasonable request.

Code availability All data generated or analysed during this study are included in this published article.

\section{Declarations}

Conflict of interest The authors declare that they have no conflict of interest.

Open Access This article is licensed under a Creative Commons Attribution 4.0 International License, which permits use, sharing, adaptation, distribution and reproduction in any medium or format, as long as you give appropriate credit to the original author(s) and the source, provide a link to the Creative Commons licence, and indicate if changes were made. The images or other third party material in this article are included in the article's Creative Commons licence, unless indicated otherwise in a credit line to the material. If material is not included in the article's Creative Commons licence and your intended use is not permitted by statutory regulation or exceeds the permitted use, you will need to obtain permission directly from the copyright holder. To view a copy of this licence, visit http://creativecommons.org/licenses/by/4.0/. 


\section{References}

1. Kaynak Y, Kitay O. The effect of post-processing operations on surface characteristics of 316L stainless steel produced by selective laser melting. Addit Manuf. 2019. https://doi.org/10.1016/j. addma.2018.12.021.

2. Xing X, Duan X, Jiang T, Wang J, Jiang F. Ultrasonic peening treatment used to improve stress corrosion resistance of AlSi10Mg components fabricated using selective laser melting. Metals (Basel). 2019. https://doi.org/10.3390/met9010103.

3. Scherillo F. Chemical surface finishing of AlSi10Mg components made by additive manufacturing. Manuf Lett. 2019. https://doi. org/10.1016/j.mfglet.2018.12.002.

4. Liu S, Guo H. Influence of hot isostatic pressing (HIP) on mechanical properties of magnesium alloy produced by selective laser melting (SLM). Mater Lett. 2020;265:127463. https://doi.org/10. 1016/j.matlet.2020.127463.

5. Wang Y, Shi J. Effect of hot isostatic pressing on nanoparticles reinforced AlSi10Mg produced by selective laser melting. Mater Sci Eng A. 2020. https://doi.org/10.1016/j.msea.2020.139570.

6. Yu H, Li F, Wang Z, Zeng X. Fatigue performances of selective laser melted Ti-6Al-4V alloy: Influence of surface finishing, hot isostatic pressing and heat treatments. Int J Fatigue. 2019. https:// doi.org/10.1016/j.ijfatigue.2018.11.019.

7. Habibiyan A, Hanzaki AZ, Abedi HR. An investigation into microstructure and high-temperature mechanical properties of selective laser-melted 316L stainless steel toward the development of hybrid ampliforge process. Int J Adv Manuf Technol. 2020. https://doi.org/10.1007/s00170-020-05870-1.

8. Uzan NE, Ramati S, Shneck R, Frage N, Yeheskel O. On the effect of shot-peening on fatigue resistance of AlSi10Mg specimens fabricated by additive manufacturing using selective laser melting (AM-SLM). Addit Manuf. 2018. https://doi.org/10.1016/j.addma. 2018.03.030.

9. Zhang P, Li SX, Zhang ZF. General relationship between strength and hardness. Mater Sci Eng A. 2011. https://doi.org/10.1016/j. msea.2011.08.061.

10. Yusuf SM, Hoegden M, Gao N. Effect of sample orientation on the microstructure and microhardness of additively manufactured AlSi10Mg processed by high-pressure torsion. Int J Adv Manuf Technol. 2020. https://doi.org/10.1007/s00170-019-04817-5.

11. Mohd Yusuf S, Nie M, Chen Y, Yang S, Gao N. Microstructure and corrosion performance of $316 \mathrm{~L}$ stainless steel fabricated by selective laser melting and processed through high-pressure torsion. J Alloys Compd. 2018. https://doi.org/10.1016/j.jallcom. 2018.05.284

12. Segal V. Equal-channel angular extrusion (ECAE): from a laboratory curiosity to an industrial technology. Metals (Basel). 2020. https://doi.org/10.3390/met10020244.

13. Valiev RZ, Langdon TG. Principles of equal-channel angular pressing as a processing tool for grain refinement. Prog Mater Sci. 2006;51:881-981. https://doi.org/10.1016/j.pmatsci.2006.02. 003.

14. Tridello A, Fiocchi J, Biffi CA, Chiandussi G, Rossetto M, Tuissi A, Paolino DS. Influence of the annealing and defects on the VHCF behavior of an SLM AlSi10Mg alloy. Fatigue Fract Eng Mater Struct. 2019. https://doi.org/10.1111/ffe.13123.

15. Salmi A, Atzeni E, Iuliano L, Galati M. Experimental analysis of residual stresses on AlSi10Mg parts produced by means of selective laser melting (SLM). In Proceedings of the procedia CIRP; 2017.

16. Ali H, Ghadbeigi H, Mumtaz K. Processing parameter effects on residual stress and mechanical properties of selective laser melted Ti6Al4V. J Mater Eng Perform. 2018. https://doi.org/10. 1007/s11665-018-3477-5.

17. Salmi A, Atzeni E. History of residual stresses during the production phases of AlSi10Mg parts processed by powder bed additive manufacturing technology. Virtual Phys Prototyp. 2017. https:// doi.org/10.1080/17452759.2017.1310439.

18. Schneller W, Leitner M, Pomberger S, Springer S, Beter F, Grün F. Effect of post treatment on the microstructure, surface roughness and residual stress regarding the fatigue strength of selectively laser melted AlSi10Mg structures. J Manuf Mater Process. 2019. https://doi.org/10.3390/jmmp3040089.

19. Fiocchi J, Tuissi A, Bassani P, Biffi CA. Low temperature annealing dedicated to AlSi10Mg selective laser melting products. J Alloys Compd. 2017. https://doi.org/10.1016/j.jallcom.2016.12. 019.

20. Rao JH, Zhang Y, Zhang K, Wu X, Huang A. Selective laser melted Al-7Si-0.6Mg alloy with in-situ precipitation via platform heating for residual strain removal. Mater Des. 2019;182:108005. https://doi.org/10.1016/j.matdes.2019.108005.

21. Snopińśki P, Tański T, Matus K, Rusz S. Microstructure, grain refinement and hardness of $\mathrm{Al}-3 \% \mathrm{Mg}$ aluminium alloy processed by ECAP with helical die. Arch Civ Mech Eng. 2019. https://doi. org/10.1016/j.acme.2018.11.003.

22. Snopiński P, Tański T, Gołombek K, Rusz S, Hilser O, Donič T, Nuckowski PM, Benedyk M. Strengthening of AA5754 aluminum alloy by DRECE process followed by annealing response investigation. Materials (Basel). 2020;13:301. https://doi.org/10.3390/ ma13020301.

23. Snopiński P, Król M. Microstructure, mechanical properties and strengthening mechanism analysis in an $\mathrm{AlMg} 5$ aluminium alloy processed by ECAP and subsequent ageing. Metals (Basel). 2018. https://doi.org/10.3390/met8110969.

24. Król M, Snopiński P, Tomiczek B, Tański T, Pakieła W, Sitek W. Structure and properties of an $\mathrm{Al}$ alloy in as-cast state and after laser treatment. Proc Est Acad Sci. 2016;65:107-16. https://doi. org/10.3176/proc.2016.2.07.

25. Trevisan F, Calignano F, Lorusso M, Pakkanen J, Aversa A, Ambrosio EP, Lombardi M, Fino P, Manfredi D. On the selective laser melting (SLM) of the AlSi10Mg alloy: process, microstructure, and mechanical properties. Materials (Basel). 2017;10(1):76.

26. Pauly S, Löber L, Petters R, Stoica M, Scudino S, Kühn U, Eckert J. Processing metallic glasses by selective laser melting. Mater Today. 2013. https://doi.org/10.1016/j.mattod.2013.01.018.

27. Aboulkhair NT, Tuck C, Ashcroft I, Maskery I, Everitt NM. On the precipitation hardening of selective laser melted AlSi10Mg. Metall Mater Trans A Phys Metall Mater Sci. 2015;46:3337-41. https://doi.org/10.1007/s11661-015-2980-7.

28. Iturrioz A, Gil E, Petite MM, Garciandia F, Mancisidor AM, San Sebastian M. Selective laser melting of AlSi10Mg alloy: influence of heat treatment condition on mechanical properties and microstructure. Weld World. 2018. https://doi.org/10.1007/ s40194-018-0592-8.

29. Li W, Li S, Liu J, Zhang A, Zhou Y, Wei Q, Yan C, Shi Y. Effect of heat treatment on AlSi10Mg alloy fabricated by selective laser melting: Microstructure evolution, mechanical properties and fracture mechanism. Mater Sci Eng A. 2016. https://doi.org/10. 1016/j.msea.2016.03.088.

30. Maeshima T, Oh-ishi K. Solute clustering and supersaturated solid solution of AlSi10Mg alloy fabricated by selective laser melting. Heliyon. 2019. https://doi.org/10.1016/j.heliyon.2019.e01186.

31. Ma A, Saito N, Takagi M, Nishida Y, Iwata H, Suzuki K, Shigematsu I, Watazu A. Effect of severe plastic deformation on tensile properties of a cast Al-11 mass\% Si alloy. Mater Sci Eng A. 2005. https://doi.org/10.1016/j.msea.2004.12.038. 
32. Ma P, Prashanth K, Scudino S, Jia Y, Wang H, Zou C, Wei Z, Eckert J. Influence of annealing on mechanical properties of Al20Si processed by selective laser melting. Metals (Basel). 2014. https://doi.org/10.3390/met4010028.

33. Zhang C, Zhu H, Liao H, Cheng Y, Hu Z, Zeng X. Effect of heat treatments on fatigue property of selective laser melting AlSi10Mg. Int J Fatigue. 2018. https://doi.org/10.1016/j.ijfatigue. 2018.07.016

34. Gao H, Huang Y, Nix WD, Hutchinson JW. Mechanism-based strain gradient plasticity - I. Theory J Mech Phys Solids. 1999. https://doi.org/10.1016/S0022-5096(98)00103-3.

35. Muñoz Morris MA, Gutierrez-Urrutia I, Morris DG. The effect of geometrically necessary dislocations on grain refinement during severe plastic deformation and subsequent annealing of Al-7\% Si. Mater Sci Eng A. 2008;493:141-7. https://doi.org/10.1016/j.msea. 2007.07.096.

36. Song D, Wang G, Zhou Z, Klu EE, Gao B, Ma A, Wu Y, Sun J, Jiang J, Ma X. Developing a high-strength Al-11Si alloy with improved ductility by combining ECAP and cryorolling. Mater Sci Eng A. 2020. https://doi.org/10.1016/j.msea.2019.138880.

37. Regina Cardoso K, Muñoz-Morris MA, Valdés León K, Morris DG. Room and high temperature ECAP processing of Al-10\% Si alloy. Mater Sci Eng A. 2013;587:387-96. https://doi.org/10. 1016/j.msea.2013.09.006.

38. Zribi Z, Ktari HH, Herbst F, Optasanu V, Njah N. EBSD, XRD and SRS characterization of a casting $\mathrm{Al}-7 \mathrm{wt} \% \mathrm{Si}$ alloy processed by equal channel angular extrusion: dislocation density evaluation. Mater Charact. 2019. https://doi.org/10.1016/j.matchar.2019.04. 044.
39. Gutierrez-Urrutia I, Muñoz-Morris MA, Morris DG. Contribution of microstructural parameters to strengthening in an ultrafinegrained Al-7\% Si alloy processed by severe deformation. Acta Mater. 2007. https://doi.org/10.1016/j.actamat.2006.09.037.

40. Haghdadi N, Zarei-Hanzaki A, Abedi HR, Abou-Ras D, Kawasaki M, Zhilyaev AP. Evolution of microstructure and mechanical properties in a hypoeutectic $\mathrm{Al}-\mathrm{Si}-\mathrm{Mg}$ alloy processed by accumulative back extrusion. Mater Sci Eng A. 2016. https://doi.org/ 10.1016/j.msea.2015.10.066.

41. Gerberich WW, Mook WM, Cordill MJ, Carter CB, Perrey CR, Heberlein JV, Girshick SL. Reverse plasticity in single crystal silicon nanospheres. Int J Plast. 2005. https://doi.org/10.1016/j. ijplas.2005.03.001.

42. Cho KT, Yoo S, Lim KM, Kim HS, Lee WB. Effect of Si content on surface hardening of $\mathrm{Al}-\mathrm{Si}$ alloy by shot peening treatment. In: Proceedings of the journal of alloys and compounds; 2011.

43. Ashby MF. The deformation of plastically non-homogeneous materials. Philos Mag. 1970. https://doi.org/10.1080/1478643700 8238426.

44. Toth L.S.; Gu C.F.; Beausir B.; Fundenberger J.J.; Hoffman M. Geometrically necessary dislocations favor the Taylor uniform deformation mode in ultra-fine-grained polycrystals. Acta Mater. 2016. https://doi.org/10.1016/j.actamat.2016.06.062.

Publisher's Note Springer Nature remains neutral with regard to jurisdictional claims in published maps and institutional affiliations. 